\title{
RMetS
}

Royal Meteorological Society

\section{The role of upper-level dynamics and surface processes for the Pakistan flood of July 2010}

\author{
O. Martius, ${ }^{\mathrm{a}, \mathrm{b} *}$ H. Sodemann, ${ }^{\mathrm{b}}$ H. Joos, ${ }^{\mathrm{b}}$ S. Pfahl, ${ }^{\mathrm{b}}$ A. Winschall, ${ }^{\mathrm{b}}$ M. Croci-Maspoli, ${ }^{\mathrm{c}}$ \\ M. Graf, ${ }^{\mathrm{b}}$ E. Madonna, ${ }^{\mathrm{b}}$ B. Mueller, ${ }^{\mathrm{b}}$ S. Schemm, ${ }^{\mathrm{b}}$ J. Sedláček, ${ }^{\mathrm{b}}$ M. Sprenger ${ }^{\mathrm{b}}$ \\ and $\mathrm{H}$. Wernli ${ }^{\mathrm{b}}$ \\ ${ }^{a}$ Oeschger Centre for Climate Change Research and Institute of Geography, University of Bern, Switzerland \\ ${ }^{\mathrm{b}}$ Institute for Atmospheric and Climate Science, ETH Zurich, Switzerland \\ ${ }^{\mathrm{c}}$ Federal Office of Meteorology and Climatology MeteoSwiss, Zurich, Switzerland \\ ${ }^{\star}$ Correspondence to: O. Martius, University of Bern, Institute of Geography, Hallerstrasse 12, CH-3012 Bern, Switzerland. \\ E-mail: olivia.martius@giub.unibe.ch or olivia.romppainen@giub.unibe.ch
}

In July and August 2010 floods of unprecedented impact afflicted Pakistan. The floods resulted from a series of intense multi-day precipitation events in July and early August. At the same time a series of blocking anticyclones dominated the upperlevel flow over western Russia and breaking waves i.e. equatorward extrusions of stratospheric high potential vorticity (PV) air formed along the downstream flank of the blocks. Previous studies suggested that these extratropical upper-level breaking waves were crucial for instigating the precipitation events in Pakistan. Here a detailed analysis is provided of the extratropical forcing of the precipitation. Piecewise PV inversion is used to quantify the extratropical upper-level forcing associated with the wave breaking and trajectories are calculated to study the pathways and source regions of the moisture that precipitated over Pakistan. Limited-area model simulations are carried out to complement the Lagrangian analysis.

The precipitation events over Pakistan resulted from a combination of favourable boundary conditions with strong extratropical and monsoonal forcing factors. Above-normal sea-surface temperatures in the Indian Ocean led to an elevated lower-tropospheric moisture content. Surface monsoonal depressions ensured the transport of moist air from the ocean towards northeastern Pakistan. Along this pathway the air parcel humidity increased substantially $(60-90 \%$ of precipitated moisture) via evapotranspiration from the land surface. Extratropical breaking waves influenced the surface wind field substantially by enhancing the wind component directed towards the mountains which reinforced the precipitation.

Key Words: heavy precipitation; Pakistan; moisture sources; evapotranspiration; potential vorticity inversion

Received 9 April 2012; Revised 24 October 2012; Accepted 1 November 2012; Published online in Wiley Online Library 12 December 2012

Citation: Martius O, Sodemann H, Joos H, Pfahl S, Winschall A, Croci-Maspoli M, Graf M, Madonna E, Mueller B, Schemm S, Sedláček J, Sprenger M, Wernli H. 2013. The role of upper-level dynamics and surface processes for the Pakistan flood of July 2010. Q. J. R. Meteorol. Soc. 139: 1780-1797. DOI:10.1002/qj.2082

1. Introduction

Between 29 July and 26 August 2010, floods in the Indus river basin of unprecedented scale afflicted Pakistan and inundated more than $20 \%$ of the country (e.g. Akthar,
2011). The water masses harmed more than 18 million people, severely damaged the infrastructure, and caused almost 2000 fatalities (USAID, 2010). Flooding occurred along the entire Indus river, which crosses Pakistan from the northeast to the southwest, and along the Swat and 
Sutlej tributaries (see Akthar (2011) for a detailed discussion of the hydrological aspects of the event and Figure 1 for geographical details). At the same time western Russia and southern Scandinavia experienced a heatwave of unprecedented magnitude (Barriopedro et al., 2011; Dole et al., 2011).

The two events were linked by a succession of largescale, upper-level flow anomalies that evolved over Europe and Asia (Hong et al., 2011; Galarneau et al., 2012; Lau and Kim, 2012). A series of blocking anticyclones, manifest as negative upper-level potential vorticity (PV) anomalies, prevented storms and frontal systems from reaching western Russia. The blocks persisted throughout the entire month of July and the blocking frequency reached values of twice the climatological frequency (Matsueda, 2011). Several breaking Rossby waves in the form of meridionally elongated and zonally narrow tongues of stratospheric high PV anomalies (corresponding to troughs in the geopotential height field) formed along the downstream edge of the blocking anticyclones (see Figure 1 and Hong et al. (2011), their Figs $2 \mathrm{c}$ and 3). These PV anomalies were important for the precipitation in Pakistan (Hong et al., 2011; Galarneau et al., 2012; Lau and Kim, 2012).

Interestingly, similar large-scale flow conditions, a highpressure system over Russia and a downstream trough over northwestern Pakistan, led to an intense precipitation event over Pakistan in July 1934, which was responsible for the tragic end of a German expedition to Nanga Parbat in northeastern Pakistan due to snowstorms (Rodewald, 1936). In this article we will address the question of how unusual the occurrence of several breaking Rossby waves to the north of Pakistan during the month of July is in a climatological context.

Studies of similar upper-level flow configurations over western Europe (i.e. a meridionally elongated positive PV anomaly) that triggered heavy precipitation events in the Alps show that the Alpine precipitation resulted from a combination of forcing factors, namely: (i) transport of moist air towards the topographic barrier; (ii) orientation of the wind field relative to the topographic barrier; (iii) a reduction of static stability underneath the positive PV anomaly; and (iv) quasi-geostrophic forcing of ascent (e.g. Massacand et al., 2001; Schlemmer et al., 2010; Winschall et al., 2011). For the heavy precipitation events in Pakistan in July 2010 the effect of the upper-level trough on moisture transport (Lau and Kim, 2011), on the static stability (Wang et al., 2011), and on the vertical wind field (Hong et al., 2011) were potentially important. One aim of this article is to complement and extend these analyses by quantifying the relative importance of each forcing factor for the processes leading to precipitation in Pakistan.

Summer precipitation over Pakistan is of monsoonal character associated with significant intraseasonal (Rahmatullah, 1952) and interannual (Webster et al., 2011) variability. Various dynamical processes on all spatial and temporal scales can play an important role in the formation of precipitation in this area, in addition to the upper-level forcing from extratropical disturbances. On the global scale, sea-surface temperatures (SST) in the Indian and Pacific Oceans, most prominently the El Niño/Southern Oscillation (ENSO) can have an impact on the monsoon precipitation over the Indian subcontinent (e.g. Palmer et al., 1992; Lau and Nath, 2000; Alexander et al., 2002). Precipitation over the Indian subcontinent exceeds the climatological mean during the cold phase of ENSO (La Niña).

On the local scale, monsoon flow phenomena are important. Rahmatullah (1952) discussed the synoptic situations that led to a very intense precipitation event in northeastern Pakistan in August 1949. He pointed to the important role of a mid-tropospheric trough over the Indian peninsula reaching from the Arabian Sea to the Bay of Bengal. The trough was associated with a low-level jet located at the eastern flank of the trough and oriented parallel to the foothills of the Himalayas from the Bay of Bengal to Pakistan. A similar strong southeasterly flow was present over the Indian peninsula during the final days of July 2010, driven by a strong pressure gradient between a strong upper-level anticyclone over Tibet and a low-level cyclonic disturbance moving across India (Houze et al., 2011; Galarneau et al., 2012; Lau and Kim, 2012)

On the mesoscale, individual vertically deep convective systems typically form over Pakistan along the boundary between dry air in the northwest and moist low-level onshore flow from the Arabian Sea during the monsoon season (Houze et al., 2007; Medina et al., 2010; Houze et al., 2011). These convective systems are of small spatial scale and we will refer to these storms as the canonical small-scale convective events hereafter.

The precipitation recorded at measurement stations in Pakistan and precipitation estimates based on satellite observations (Webster et al., 2011; see also Figures 2 and 5) show that several multi-day rain events of increasing amplitude affected central and northern Pakistan during July 2010. In this article we focus on the dynamics that governed the evolution of the last two of these extreme precipitation events, i.e. the event from 20 to 23 July and the event from 28 to 30 July (Figure 2). The event from 28 to 30 July was the main atmospheric trigger of the first flooding episode (Akthar, 2011).

Compared to the canonical small-scale convective events, both precipitation events had different characteristics. The precipitation during 20 to 23 July was 'squall line type of organized convection with trailing stratiform rainfall typical for synoptic influence' (Wang et al., 2011). Satellitebased analyses by Houze et al. (2011) show large stratiform precipitation areas that developed from convective storms through interaction with the orography during the second event. These highly unusual mesoscale convective storms (MCS) formed in nearly saturated environmental conditions throughout the lower and middle troposphere (Houze et al., 2011; Galarneau et al., 2012, their Fig. 3). Such humidity conditions in the free troposphere are very unusual for Pakistan (Medina et al., 2010).

Given the important role of abundant moisture supply for the formation of intense precipitation events (e.g. Doswell et al., 1998; Wang et al., 2011), it is interesting to investigate the origin and transport pathways of the involved humidity. Pakistan is climatologically located at the northern edge of a band of intense moisture transport from the Arabian Sea to the Indian subcontinent during summer (Trenberth, 1999). Besides moisture transport, recycling of moisture over land is also important for precipitation in northeastern Pakistan (Trenberth, 1999). Consistent with these findings, soil moisture feedbacks are relevant for precipitation in the drier regions of the Indian subcontinent (Yasunari, 2006), especially during monsoon onset and retreat (Tuinenburg et al., 2011). We investigate both moisture source areas and 
(a)

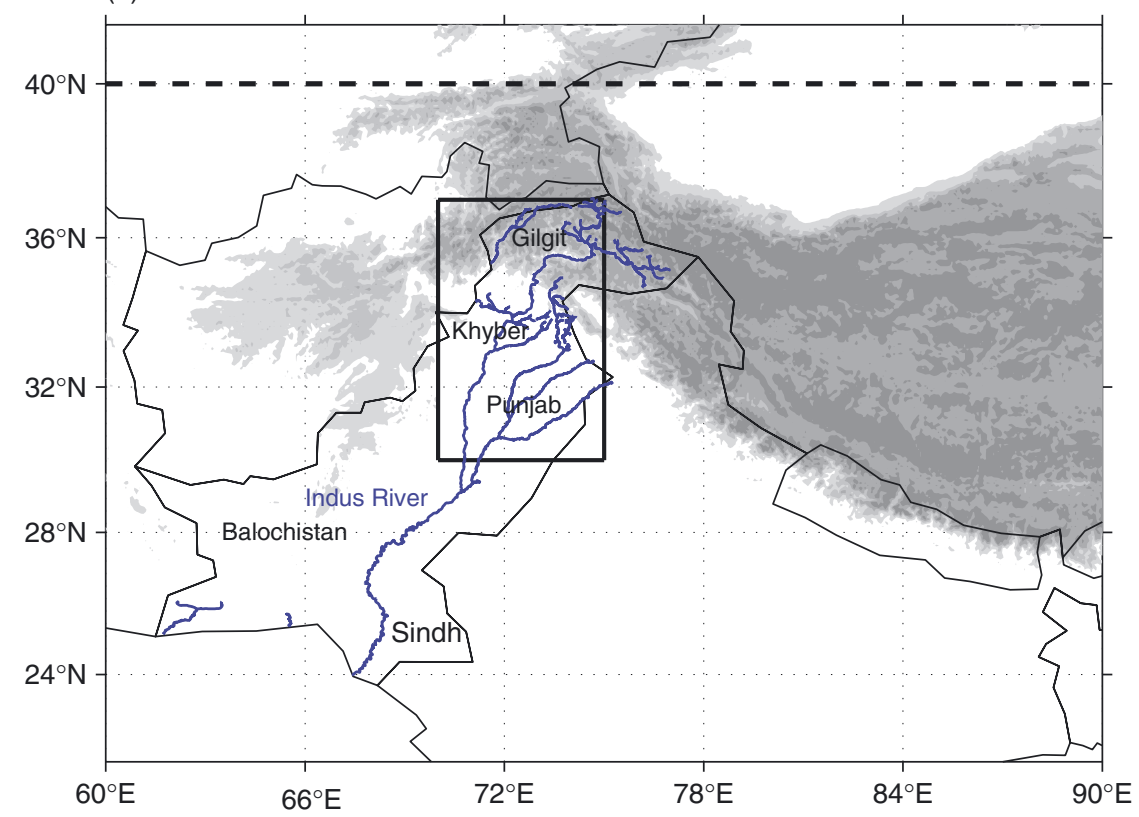

(b)

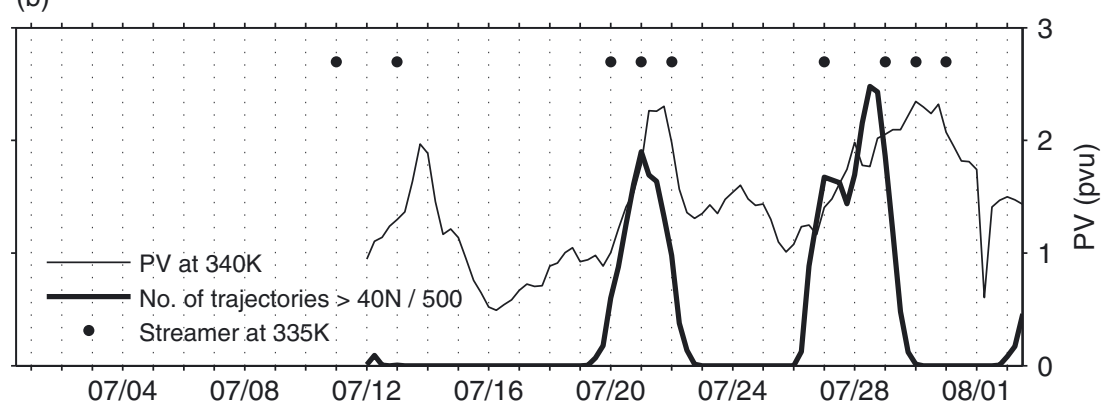

Figure 1. (a) Map showing the topography (grey shading 1000, 2000 and $3000 \mathrm{~m}$ a.s.l.), the provinces of Pakistan, major rivers, the domain used for trajectory and time-series calculations (black rectangle) and $40^{\circ} \mathrm{N}$ isoline (black dashed line). (b) Area mean $\mathrm{PV}\left(60^{\circ} \mathrm{E}-70^{\circ} \mathrm{E}, 30^{\circ} \mathrm{N}-40^{\circ} \mathrm{N}, \mathrm{PVU}\right.$, thin black line), objectively identified wave-breaking events on $335 \mathrm{~K}$ (dots) and number of trajectories crossing the Himalaya, defined here as crossing $40^{\circ} \mathrm{N}$, divided by 500 (thick black line). The total number of trajectories is 2600 . A value of 2.2 corresponds to approximately $50 \%$ of the trajectories crossing the mountains. This figure is available in colour online at wileyonlinelibrary.com/journal/qj

the role of low-level and upper-level flow features for the transport of moisture into Pakistan.

In summary, the aims of this article are: (i) to describe the large-scale and local-scale flow characteristics that resulted in the severe flood event in Pakistan, and to link them to a detailed analysis of the origin and pathways of the moisture that rained out over Pakistan; (ii) to analyse in detail extratropical forcing factors of the precipitation events in Pakistan; and (iii) to address the question of how unusual the large-scale flow configuration was in a climatological context.

\section{Data and methods}

\subsection{Datasets}

We used the ERA-Interim dataset (Dee et al., 2011) for the years 1989-2010 for all climatological analyses presented in section 4, for the quasi-geostrophic vertical motion analysis, the PV inversion and for the FLEXPART trajectory calculations. ERA-Interim data are available with a 6-hourly temporal resolution and the fields were interpolated to a regular $1^{\circ}$ by $1^{\circ}$ grid. Note that the ERA-Interim evaporation field is a prognostic variable and not constrained by direct observations.

We used European Centre for Medium-range Weather Forecasts (ECMWF) operational analysis data interpolated to $0.4^{\circ}$ resolution for the event-specific trajectory calculations and the detailed synoptic description presented in section 5 . The 6-hourly accumulated fields of precipitation and evaporation stem from the ECWMF short-range forecasts dataset and were interpolated to a $0.4^{\circ}$ by $0.4^{\circ}$ grid. Both fields are prognostic and therefore not constrained by direct observations. We used forecast steps 6 to 12 hours and 12 to 18 hours to derive the 6-hourly values. The quality of the Integrated Forecast System (IFS) model-generated soil moisture fields is overall very good; however, in the July 2010 model version, soil moisture was overestimated and evaporation underestimated over dry lands (Albergel et al., 2012). Breaking Rossby waves were identified using the objective detection algorithm of Wernli and Sprenger (2007) and aggregated vertically from $310 \mathrm{~K}$ to $360 \mathrm{~K}$.

We also used daily accumulated 3B42 Tropical Rainfall Measuring Mission (TRMM) precipitation data with a $0.25^{\circ}$ spatial resolution (Huffman et al., 2001, 2007). In addition we used observed daily accumulated (from 0300 to 0300 UTC) rain-gauge data made available by the 
(a)

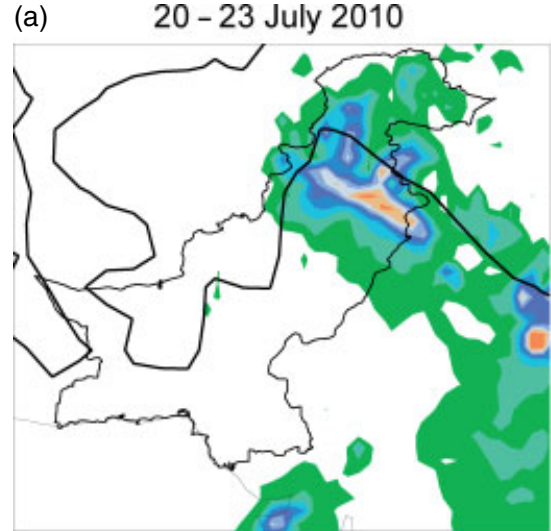

(c)

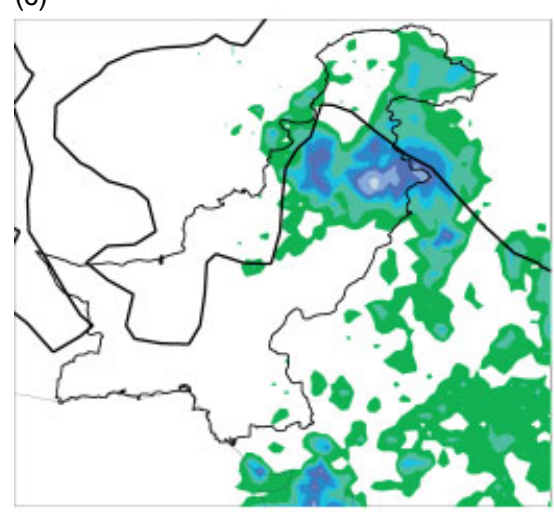

(e)

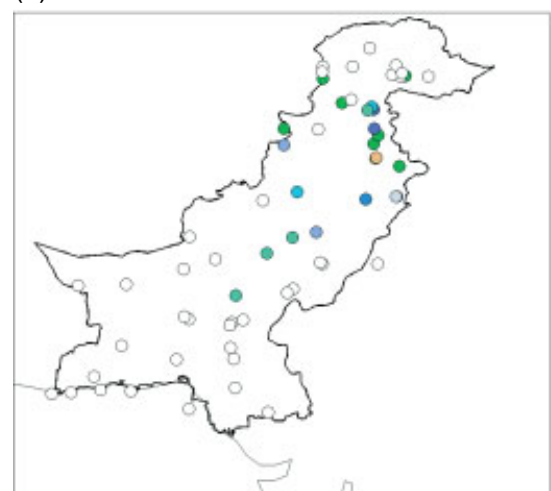

(b)

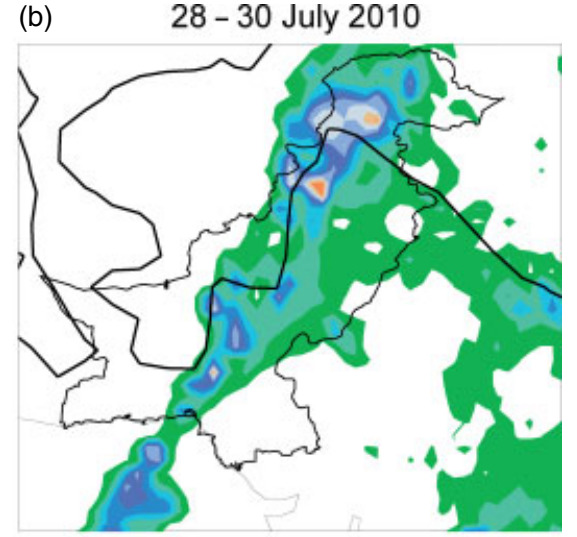

(d)

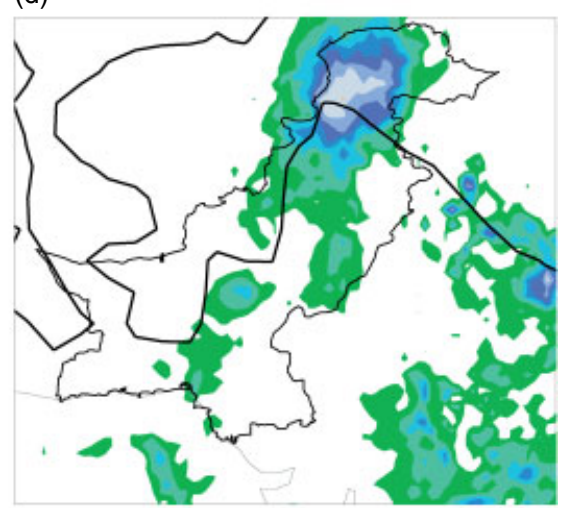

(f)

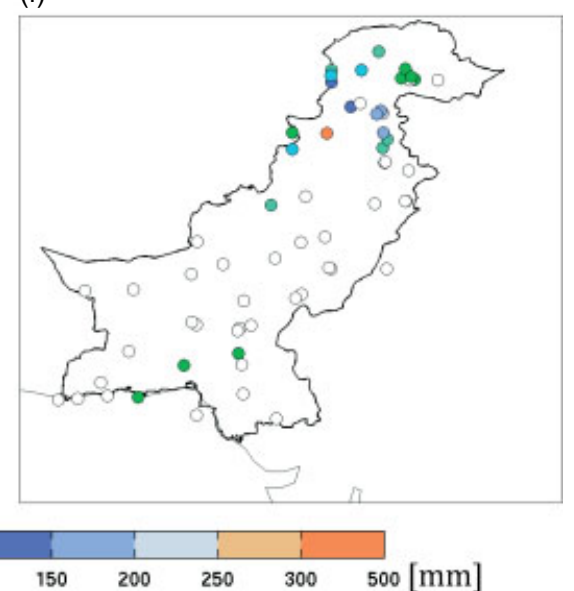

Figure 2. Accumulated precipitation from the ECMWF short-range forecasts (a) between 0000 UTC 20 July and 0000 UTC 23 July 2010 and (b) between 0000 UTC 28 July and 0000 UTC 31 July; from TRMM observations (c) between 0000 UTC 20 July and 0000 UTC 23 July and (d) between 0000 UTC 28 July and 0000 UTC 31 July; and from rain-gauge observations (e) between 0300 UTC 20 July and 0300 UTC 23 July and (f) between 0300 UTC 28 July and 0300 UTC 31 July. For a better orientation the $1000 \mathrm{~m}$ a.s.l. contour is added in panels (a), (b), (c), and (d) (thick black line).

Pakistan Meteorological Department on their website for the months of June, July and August $2010 .^{\dagger}$ We used a subset of 62 stations where the exact location information (latitude/longitude and elevation) of the stations was available through the website of the Pakistan Meteorological Department.

Monthly changes in total terrestrial water storage, which includes groundwater, soil moisture, surface water, snow, ice and biomass, were obtained from the GRACE satellites (Swenson and Wahr, 2006). Sounding data from Srinagar $\left(34.5^{\circ} \mathrm{N}, 74.5^{\circ} \mathrm{E}, 1587 \mathrm{~m}\right.$ a.s.l.) available at $0000 \mathrm{UTC}$

${ }^{\dagger}$ http://www.pakmet.com.pk/FFD/index_files/rainfalljuly10.htm.
(0530 local time) were downloaded from the University of Wyoming website.

\subsection{Trajectory calculations}

Air mass transport characteristics were investigated with trajectories calculated with the Lagranto trajectory tool (Wernli and Davies, 1997). The trajectories were started from a $0.4^{\circ}$ by $0.4^{\circ}$ grid in a rectangular box located over northeastern Pakistan $\left(30^{\circ} \mathrm{N}\right.$ to $37^{\circ} \mathrm{N}$ and $70^{\circ} \mathrm{E}$ to $75^{\circ} \mathrm{E}$, box in Figure 1(a)), and calculated forward in time for 48 hours

\footnotetext{
${ }^{\ddagger} \mathrm{http} / / /$ weather.uwyo.edu/upperair/sounding.html.
} 

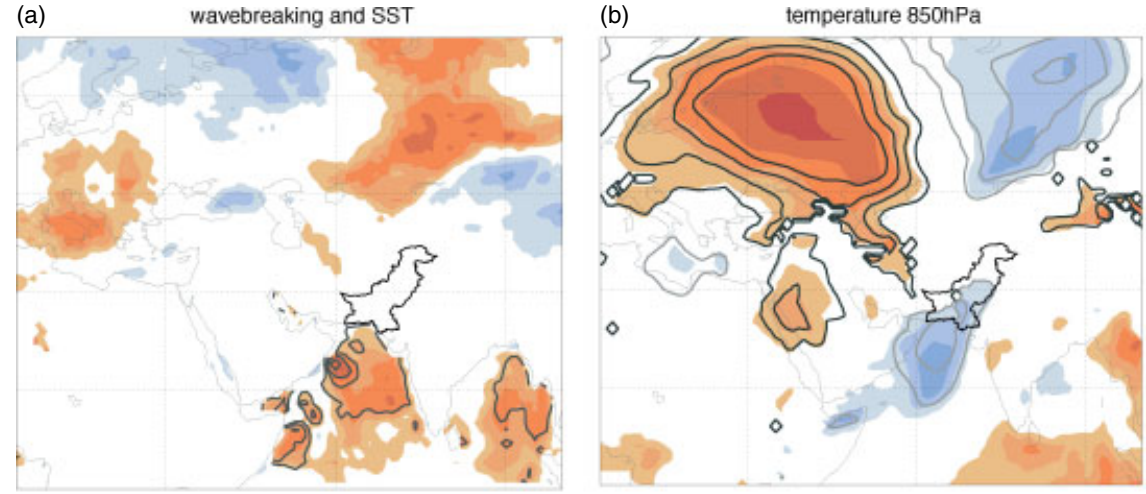

(c)

(d)

relative humidity $850 \mathrm{hPa}$
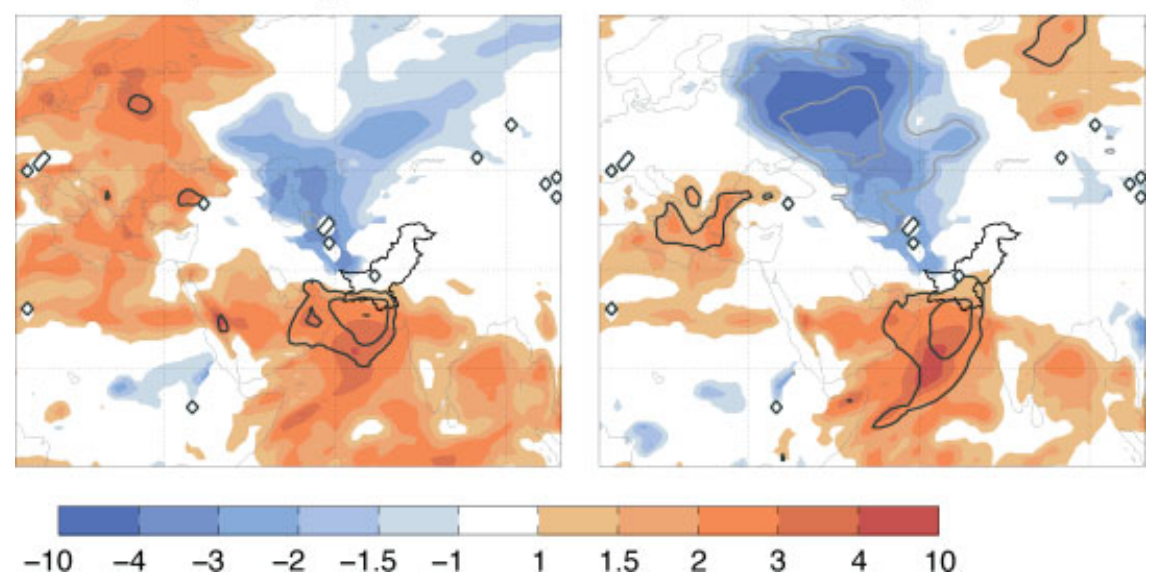

Figure 3. (a) Normalized monthly anomalies $\left(\frac{\text { mean }_{\text {July } 2010}-\text { mean }_{\text {July ERA-interim }}}{\text { STD }_{\text {July ERA-interim }}}\right)$ of the frequency of breaking waves $\left(\right.$ shaded areas north of $\left.30^{\circ} \mathrm{N}\right)$ and SSTs (shaded areas south of $30^{\circ} \mathrm{N}$ ) and absolute SST anomalies (black lines for 1, 1.5, $2 \mathrm{~K}$ ), (b) normalized temperature anomalies on 850 hPa (shaded) and absolute anomalies (solid black and grey lines for $\pm 1, \pm 2, \pm 3, \pm 4 \mathrm{~K}$ ), (c) normalized specific humidity anomalies at 850 hPa (shaded) and absolute anomalies (sold black and grey lines for $\pm 2, \pm 3, \pm 4 \mathrm{~g} \mathrm{~kg}^{-1}$ ), (d) normalized relative humidity anomalies at $850 \mathrm{hPa}$ (shaded) and absolute anomalies (solid black and grey lines for $\pm 10, \pm 20, \pm 30 \%$ ).

and backward in time for 96 hours. The trajectories were started every 6 hours between 0000 UTC 18 July and 0000 UTC 31 July from the layer between the surface and $200 \mathrm{hPa}$ (back trajectories) and between the surface and $750 \mathrm{hPa}$ (forward trajectories). The back trajectories were started from areas over northeastern Pakistan where the relative humidity exceeded $95 \%$. We use this criterion as a proxy for the cloud layer producing precipitation. Temperature, pressure, absolute and relative humidity, and surface evapotranspiration (all fields from the ECMWF) were traced along the trajectories at a 6-hour time interval.

\subsection{Moisture source diagnostics}

Moisture source regions were identified using the Lagrangian moisture source diagnostic of Sodemann et al. (2008) based on calculations with the Lagrangian particle dispersion model FLEXPART (Stohl et al., 2005; Sodemann and Stohl, 2009). An advantage of this model compared to conventional trajectory models is that it includes parametrizations for turbulent and convective motions in the atmosphere, the latter being particularly relevant in a subtropical environment. Vertical particle motion due to moist convection is calculated within the FLEXPART model using the mass-flux parametrization of Emanuel and Živković-Rothman (1999). For the identification of precipitation sources during July 2010, the atmosphere over the target domain $\left(30^{\circ} \mathrm{N}-37^{\circ} \mathrm{N}\right.$ and $70^{\circ} \mathrm{E}-75^{\circ} \mathrm{E}$, box in Figure 1(a)) was divided into 40000 particles of equal mass and advected for 20 days backward in time using 6hourly ECMWF re-analysis wind fields, supplemented by 3-hourly forecast fields. New particles were continuously generated to keep track of the whole mass in the domain during the period from 1 May to 31 August 2010 (socalled domain-filling calculation mode). Specific humidity and other meteorological variables are interpolated at the parcels' positions from the ECMWF data at each output interval (here, 3 hours). The moisture source diagnostic then quantitatively identifies moisture source regions from the 3-hourly changes in specific humidity along the parcels' backward trajectories. Increases in specific humidity that take place while an air parcel is lower than 1.5 times the boundary-layer height are assumed to be due to entrainment/mixing of moisture from the surface into air parcels. The boundary-layer height used for the diagnostic is calculated within FLEXPART from a critical Richardson number parametrization (Vogelezang and Holtslag, 1996). Considering the temporal sequence of humidity increases (from evaporation) and decreases (from precipitation) along a parcel's trajectory allows for a quantitative estimate of the relevance of more local versus distant moisture uptake events for the final precipitation in the target domain (for further details see Sodemann et al., 2008). The quantitative information derived from this method is summarized in 
maps showing a subset of the total evaporation contributing to precipitation in the target area in units of $\mathrm{mm} \mathrm{day}^{-1}$ (see section 7).

\subsection{COSMO simulations}

To investigate the impact of regional evapotranspiration from land surfaces on the precipitation in Pakistan, simulations were performed with the non-hydrostatic limited-area model COSMO (Doms and Schättler, 2002; Steppeler et al., 2003), which is operationally used for weather forecasting by several European weather services, including the German weather service DWD and MeteoSwiss. Dobler and Ahrens (2010) showed that the COSMO model is well suited to capture the relevant processes of the Indian monsoon system. They noted, however, that the model generally underestimates the precipitation in the Himalayan foothills.

In this study, COSMO version 4.11 has been applied for simulating the heavy precipitation in Pakistan between 28 and 30 July 2010. Seven-day hindcast simulations, initialized with and driven at the boundaries by operational ECMWF analysis data were conducted starting at 0000 UTC 24 July 2010. The model was run with a horizontal resolution of $0.0625^{\circ}$ (about $7 \mathrm{~km}$ ), 40 hybrid vertical levels and a time step of 40 seconds, using a Runge-Kutta time integration scheme (see Doms and Schättler (2002) and references therein for further details). A modified Tiedtke scheme was applied for the parametrization of moist convection. The model domain, consisting of $560 \times 480$ grid points in the horizontal, covers parts of the Indian subcontinent and the Indian Ocean, southwestern Asia and the Arabian Peninsula (Figure 10(b)). The land evapotranspiration of moisture in the COSMO model is parametrized with a flux-gradient approach, in which turbulence and the moisture gradient between the surface and the first model level determine the strength and direction of the moisture flux. The land surface model of COSMO uses plant cover as an input parameter to calculate the transpiration for every grid point following the parametrization of Dickinson (1984).

In addition to a reference run with full model physics, a sensitivity experiment was performed. For the experiment the evaporation fluxes from the land surface were suppressed in an area covering parts of Pakistan and northwestern India (black box in Figure 12(b)) during the last six days of the simulation (i.e. three days before the start of the heavy precipitation event). With this set-up, the suppressed humidity flux into the atmosphere was not compensated by the model through an increased surface sensible heat flux. The experiment is used for investigating the impact of local evapotranspiration on the moisture supply for the precipitation event.

\subsection{Piecewise PV inversion}

The quasi-geostrophic piecewise PV inversion tool of Fehlmann (1997) (see also Sprenger, 2007; Schlemmer et al., 2010) was used to determine the effects of the upper-level positive PV anomalies on the tropospheric stability and the low-level flow. The PV anomaly was defined as the positive deviation of the total PV from its zonal average value within the inversion domain. For the inversion domain a box was chosen with the centre located at $38^{\circ} \mathrm{N} 60^{\circ} \mathrm{E}$. The size of the box was $1200 \mathrm{~km}$ in both horizontal directions and in the vertical the inversion domain extended from 5 to $12 \mathrm{~km}$.

\section{Precipitation}

The precipitation in Pakistan in July 2010 fell in several multi-day episodes of increasing intensity (Fig. 5, Webster et al., 2011). Precipitation totals were largest in the northeastern provinces of Punjab, Gilgit and Khyber (Akthar (2011), see also Figure 2). Webster et al. (2011) stated that the July mean precipitation over Pakistan 2010 was high but not extreme; however, the number of individual extreme precipitation events (defined as 2-day accumulated rainfall exceeding $20 \mathrm{~mm}$ ) was very unusual, potentially exceeding a 30 -year return period.

Especially during the last precipitation episode (28 to 30 July) very large amounts of precipitation fell in some areas. The 24-hour accumulated precipitation registered at some measurement stations exceeded the climatological July precipitation (Akthar, 2011).

The accumulated precipitation between 20 and 23 July (penultimate event) and between 28 and 31 July 2010 (final event) as registered in the TRMM dataset, the ECMWF short-range forecast and at the weather stations is shown in Figure 2. During the first precipitation event, precipitation maxima were registered at elevations between 0 and $1500 \mathrm{~m}$ a.s.l. just south of the Himalaya mountains and along the first mountain range. The spatial agreement between the ECMWF forecast, the TRMM observations and the surface stations is relatively good. Compared to the observations the amplitude of the event is overestimated by the ECMWF model (only one station registered more than $250 \mathrm{~mm}$, while according to the ECMWF model a broader area received more than $250 \mathrm{~mm}$ ). With the exception of the one station that registered more than $250 \mathrm{~mm}$ the TRMM observations agree quite well with the surface observations.

During the second event the precipitation maxima were located in the Karakorum mountains, along the Himalayas in the Peshawar area, and further west in the Hindu Kush mountains. Both the ECMWF model and the TRMM observations locate the precipitation maximum on the border with Afghanistan in the Hindu Kush mountains. The surface observations also registered significant amounts of precipitation in the lower-lying areas around Peshawar. Overall there is good agreement between all datasets regarding the amplitude of the precipitation event. Both the ECMWF model data and the observations contain peak precipitation values of more than $300 \mathrm{~mm}$.

\section{Large-scale circulation and hydro-climatological conditions}

The aims of this section are: (i) to describe the large-scale flow situation over Asia during July; (ii) to address the question of how unusual this large-scale flow setting was compared to a 20-year climatology; and (iii) to identify forcing factors and boundary conditions that potentially enhanced the heavy precipitation events in Pakistan. All anomalies presented in this section are anomalies to the 1989 to 2009 ERA-Interim July mean values and are normalized by the respective interannual standard deviation (STD).

\subsection{Large-scale flow and sea-surface temperature anomalies}

On a global scale the large-scale flow during June, July and August 2010 was characterized and influenced by La Niña conditions in the Pacific basin. Conditions had changed 


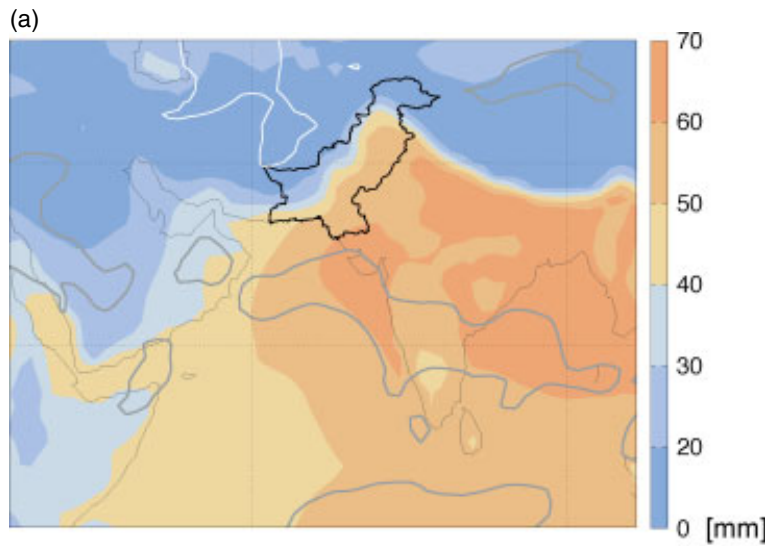

(b)

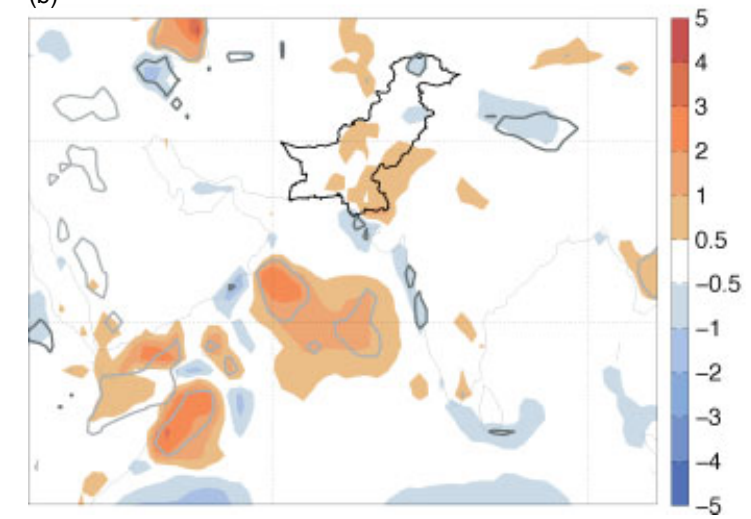

Figure 4. (a) July 2010 mean PW (mm, shaded) and contours of normalized anomalies (grey $=+2$ STD, white $=-2$ STD). (b) Absolute July 2010 evaporation anomalies $\left(\mathrm{mm}(12 \mathrm{~h})^{-1}\right.$, shaded) and contours of normalized anomalies (light grey $=+2 \mathrm{STD}$, dark grey $=-2 \mathrm{STD}$ ).

from an El Niño state in winter to a La Niña situation in late spring. Consistently above-normal SSTs were present in the Indian Ocean in July 2010 (1-3 STD, between 0.5 and $1 \mathrm{~K}$, Figure 3(a)).

A series of quasi-stationary blocking anticyclones were located over western Russia during July 2010 (Matsueda, 2011). Blocking anticyclones are more prevalent in this area during La Niña conditions (Schneidereit et al., 2012). Downstream of the block, anticyclonic wave breaking brought stratospheric high-PV air south toward Afghanistan and northern Pakistan (Figures 1, 3(a) and 6(a)). This joint occurrence of blocking and wave breaking along the downstream flank of the block is relatively common and helps to ensure the stationarity of the blocking anticyclones against the mean flow. The flow field of the blocking anticyclone supports the formation of the breaking waves along the downstream flank of the anticyclone (Altenhoff et al., 2008). The frequency of objectively identified wavebreaking events was highly unusual (1-3 standard deviations (STD), Figure 3(a)). Four wave-breaking events, which reached far enough equatorward to affect Pakistan, occurred in July 2010. The four events occurred concomitantly with the precipitation events (Figures 1 and 5).

\subsection{Atmospheric humidity and soil moisture}

Positive absolute humidity anomalies prevailed across the Arabian Sea and India throughout the lower to middle troposphere. The positive anomalies were not significant near the sea surface but exceeded two standard deviations above the $925 \mathrm{hPa}$ level up to $700 \mathrm{hPa}$, indicating a vertically deep layer of anomalously moist air. This is reflected in elevated precipitable water (PW) values over the Indian Ocean and southern India ( $>2$ STD, Figure 4(a)).

Temperatures over Pakistan and the Arabian Sea between $925 \mathrm{hPa}$ and $700 \mathrm{hPa}$ were below normal during July 2010 (1-2 STD at $850 \mathrm{hPa}$, Figure 3(b)) indicating that the relative humidity was anomalously high. Indeed the relative humidity at $850 \mathrm{hPa}$ was approximately $1.5 \mathrm{STD}$ above normal over southwestern Pakistan (Figure 3(d)) and anomalously high between $925 \mathrm{hPa}$ and $700 \mathrm{hPa}$.

The July-mean PW reached $66 \mathrm{~mm}$ along the Himalayan foothills in India and $55 \mathrm{~mm}$ over northeastern Pakistan (Figure 4(a)). This compares to $30-40 \mathrm{~mm}$ in the June to September climatological mean (Medina et al., 2010, their Fig. 2). A very strong gradient in PW of more than $30 \mathrm{~mm}$ was present over Pakistan separating drier air masses in the northwest from moist air masses in the southeast (Figure 4(a)). The PW gradient exceeded the June to September climatological mean by about $10 \mathrm{~mm}$ (Medina et al., 2010, their Fig. 2a). During the course of the month this boundary successively shifted northwestward and the moist air reached northeastern Pakistan towards the end of July (Figure 5). Compared to the ERA-Interim July climatology, PW was about $5 \mathrm{~mm}$ (approximately 2 STD) above normal in southern India, slightly above normal in eastern Pakistan and over the Indus valley, and below normal (2 STD) to the west of Pakistan (Figure 4(a)).

Over the ocean, evaporation maxima were present throughout July 2010 in the central Arabian Sea underneath the Somali Jet and to the east of the southern tip of India. Comparing the evaporation over Pakistan in the month of July 2010 with climatology, positive anomalies of 0.5 to $1 \mathrm{~mm}$ $(12 \mathrm{~h})^{-1}$ occurred over southwestern Pakistan and along the foothills of the Himalayas over India (Figure 4(b)). The amplitude of these differences corresponded to 1-1.5 STD over India and Pakistan. In agreement with the anomalously warm SSTs of the Indian Ocean a strong positive evaporation anomaly ( $>2$ STD) was located underneath the Somali Jet (Figure 4(b)).

Moisture source calculations with FLEXPART (as described in section 2.3) revealed that climatologically the main source areas for moisture that rains out over northeastern Pakistan in July are located over Pakistan, along the foothills of the Himalayas in India, and over the Arabian Sea between the Arabian Peninsula and the area of the Somali Jet (not shown). Evapotranspiration over the Indian subcontinent is hence a relevant moisture source for precipitation events over Pakistan. In this context, it is interesting to look at soil moisture conditions in July 2010. GRACE terrestrial water storage data indicate that the terrestrial water storage over Pakistan was slightly below normal for the entire spring and early summer (not shown). Conditions were also drier than normal along the foothills of the Himalayas.

In summary, both the frequency of heavy precipitation events over northern Pakistan (Webster et al., 2011) and the frequency of breaking waves over central Asia (Figure 3(a)) were anomalously high compared to climatology. In addition, above-average SST conditions in the Indian Ocean were potentially promoting stronger evaporation and positive lower to mid-tropospheric absolute moisture anomalies over the Indian Ocean (Figure 3). 


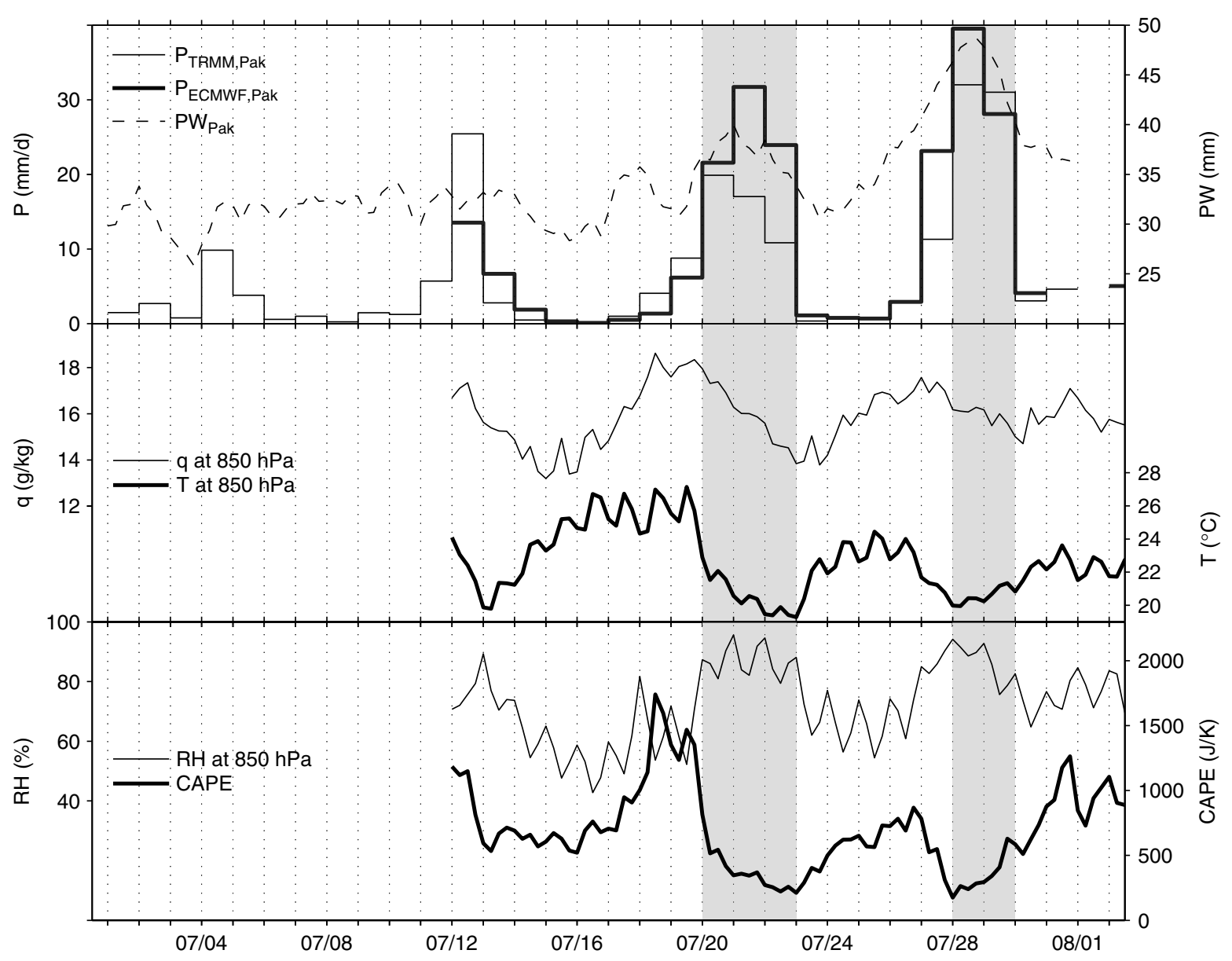

Figure 5. Time evolution of the area averaged (see Figure 1 for the average domain) ECWMF precipitation, TRMM precipitation and ECMWF precipitable water (top), specific humidity at $750 \mathrm{hPa}$ and temperature at $850 \mathrm{hPa}$ (centre), and relative humidity at $850 \mathrm{hPa}$ and most unstable CAPE (bottom). The grey bars indicate the precipitation events investigated in this study.

\section{Detailed description of the precipitation events}

This section provides a synoptic description of the two precipitation events in the second half of July 2010 that brought large amounts of the precipitation to northeastern Pakistan (see also Figure 2).

\subsection{First precipitation event (19 to 22 July 2010)}

A dry period, lasting from 13 to 18 July, preceded this precipitation episode (Figure 5). This dry period was characterized by a temperature increase over northeastern Pakistan (Figure 5), leading to the formation of a heat-low over central Pakistan (Figure 6(b)). Concomitantly an anticyclonic flow anomaly had formed at upper levels over northern Pakistan on 17 July in response to intense tropical convection over the Bay of Bengal (not shown). The anticyclonic flow anomaly was characterized by very dry upper-level air, subsidence, and clear sky conditions. As a consequence the surface heat-low over Pakistan intensified markedly on 18 July and underneath the anticyclonic flow anomaly an inversion layer was present over northeastern Pakistan until 19 July (information from sounding data, not shown). Beneath the inversion layer the absolute moisture in the lower troposphere increased over time (Figure 5) and convective available potential energy (CAPE) values averaged over northeastern Pakistan reached a maximum value of $1750 \mathrm{~J} \mathrm{~kg}^{-1}$ on $18 \mathrm{July}$ (Figure 5). This flow situation is the typical setting for the canonical small-scale convection over Pakistan (Houze et al., 2007; Medina et al., 2010).

From 18 July onward, northeastward surface winds along the southern edge of the heat-low transported moist air from the Arabian Sea towards northeastern Pakistan (Figure 6(b)) and at the same time an evaporation maximum was located over northeastern Pakistan (Figure 6(b)). The flow forced by the heat-low therefore connected the strong low-level jet over the Arabian Sea (Somali Jet) with northeastern Pakistan. This is confirmed by a set of backward trajectories started at 0000 UTC 22 July over northeastern Pakistan from the precipitation area. One branch of air masses that reached northeastern Pakistan originated from the Arabian Sea (Figure 7(a)).

A first convective storm formed on the eastern flank of the heat-low along the foothills of the Himalaya on 19 July as seen from geostationary satellite imagery (not shown). The location of the convective storm in the foothills of the mountains is very characteristic for convection in this area that is typically triggered by orographic lifting (Houze et al., 2007).

After the onset of the precipitation on 19 July the area-average temperature at $850 \mathrm{hPa}$ over northeastern Pakistan decreased by approximately six degrees within four days and the area-averaged absolute moisture decreased as well (Figure 5). Concomitantly the area-averaged relative humidity at $850 \mathrm{hPa}$ increased from approximately $65 \%$ to $95 \%$ (Figure 5) and relative humidity in the upper 

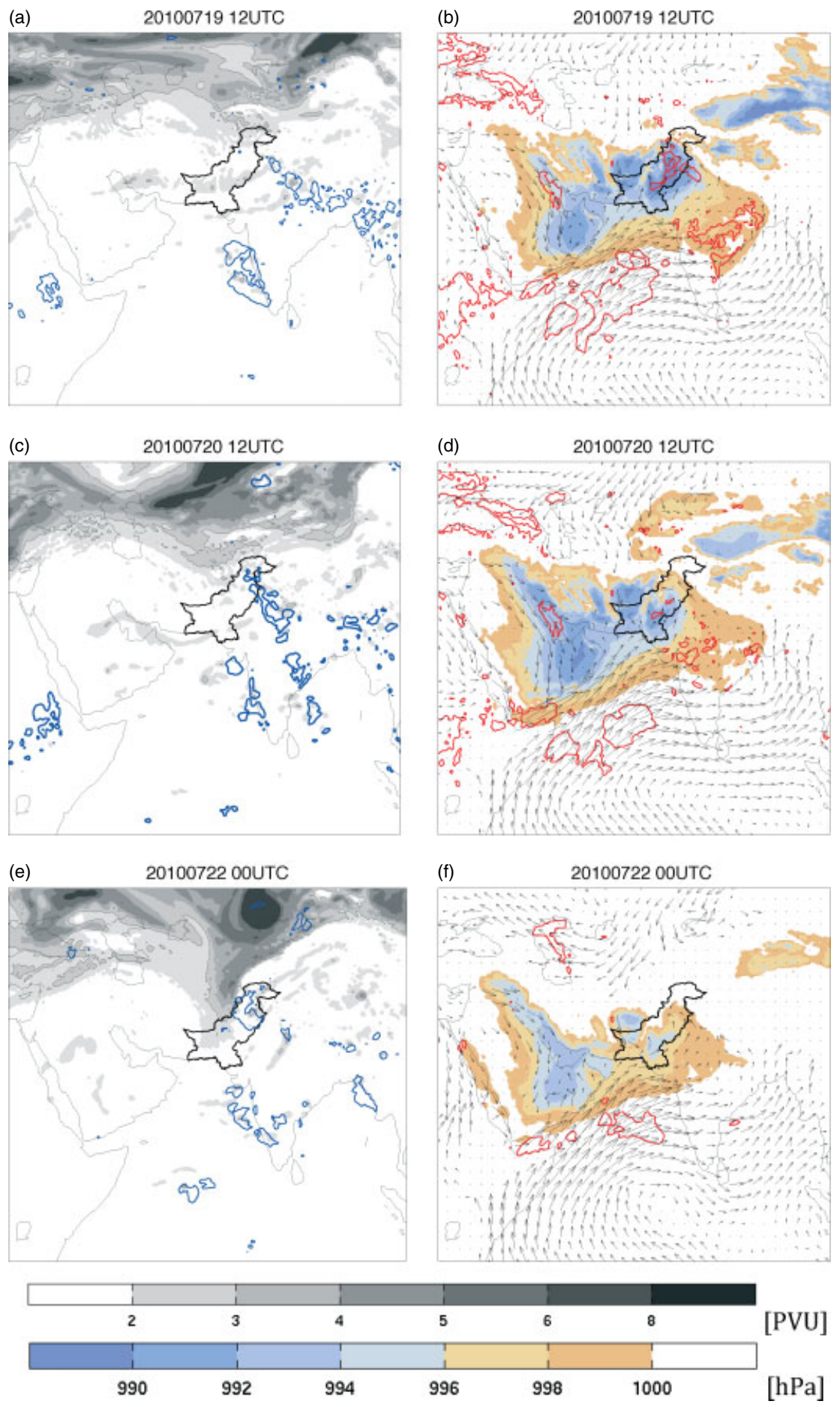

Figure 6. Left column: the ECMWF analysis of the PV on $340 \mathrm{~K}$ (shaded, $\mathrm{PVU}$ ) and the ECMWF prognostic precipitation (blue contours, $10 \mathrm{~mm}(6 \mathrm{~h})^{-1}$ ) for (a) 1200 UTC 19 July, (c) 1200 UTC 20 July, (e) 0000 UTC 22 July 2010. Right column: the ECMWF analysis of the surface pressure (shaded, hPa) and wind velocity at $925 \mathrm{hPa}$ (black arrows, $\mathrm{m} \mathrm{s}^{-1}$ ) and the prognostic evaporation (red lines, $2.5 \mathrm{~mm}(6 \mathrm{~h})^{-1}$ ) for (b) 1200 UTC 19 July, (d) 1200 UTC 20 July and (f) 0000 UTC 22 July. Note that both the surface pressure and the evaporation undergo a strong diurnal cycle and that not all panels show the same time of the day.

troposphere increased from very low values on 18 July to saturation up to almost $200 \mathrm{hPa}$ on 22 July (not shown), and CAPE values averaged over northeastern Pakistan dropped to approximately $250 \mathrm{~J} \mathrm{~kg}^{-1}$ on 21 July. The high relative humidity values in the free troposphere from 20 July onwards are atypical for eastern Pakistan and a necessary condition for the formation of convective storms of larger spatial scale with stratiform characteristics (Houze et al., 2011). A detailed discussion of the source of the mid-tropospheric moisture is presented in section 7 .
In summary, initially an upper-level anticyclonic flow anomaly led to an intensification of the heat-low by clear sky conditions and suppressed the release of convection via the formation of a capping inversion. The heat-low over central Pakistan intensified the transport of moist air from the Arabian Sea into Pakistan. On 19 July the upperlevel anticyclonic anomaly weakened, moved westward and convection set in over northwestern Pakistan.

On 21 July a breaking wave, i.e. a positive upper-level PV anomaly, which had previously formed along the eastern 
(a)

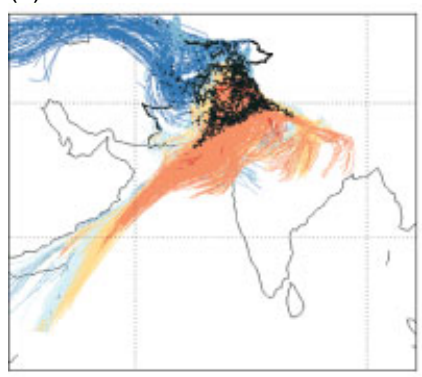

(c)

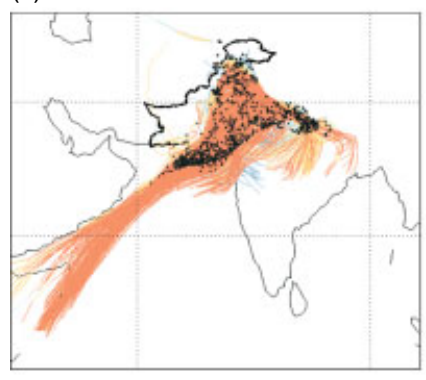

(e)

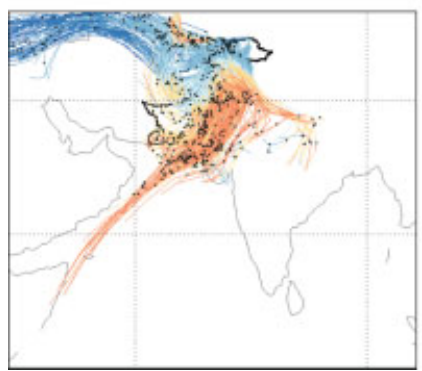

(b)

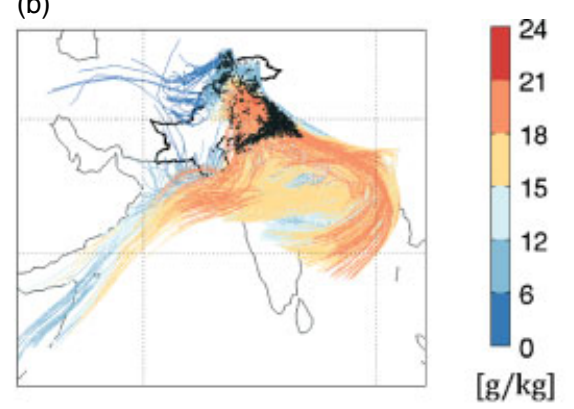

(d)

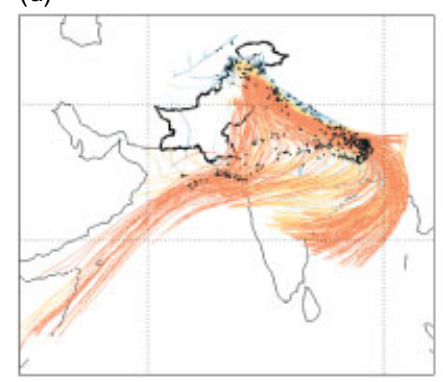

(f)

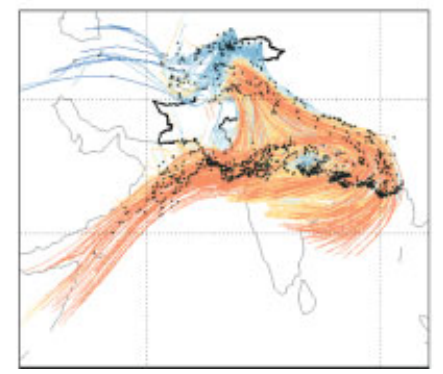

1000

900

800

700

500

200

[hPa]

Figure 7. Back trajectories started from a box over northeastern Pakistan (Figure 1) from grid points with $\mathrm{RH}>95 \%$ between the surface and 200 hPa (a) at 0000 UTC 22 July and (b) at 0600 UTC 29 July 2010. The colour indicates the absolute moisture ( $\left.\mathrm{g} \mathrm{kg}^{-1}\right)$ along the trajectories, the black dots indicate the position of the trajectories at -24 hours. A subset of the trajectories that are located below $700 \mathrm{hPa}$ over Pakistan at $t=0$ is shown in panels (c) and (d) to illustrate the height (shading, hPa) and temporal progress; the black dots indicate the location at -48 hours of the trajectories. Panels (e) and (f) shows the subset of trajectories that are located above $700 \mathrm{hPa}$ over Pakistan at $t=0$. The black dots indicate the position at -72 hours. The shading indicates the height $(\mathrm{hPa})$.

flank of the blocking anticyclone over Russia, reached northern Pakistan. A precipitation maximum was located along the eastern flank of the upper-level breaking wave (Figure 6(e)). A change in characteristics of the precipitation is clearly visible in geostationary infrared satellite pictures. From 21 July onward, clouds of stratiform habit with interspersed MCSs (see also Wang et al., 2011) covered northeastern Pakistan. The positive upper-level PV anomaly provided large-scale forcing (weak quasi-geostrophic forcing of ascent and low-level flow alteration) that enhanced this second stage of the precipitation event and potentially prolonged the precipitation through to 22 July. A detailed discussion of the upper-level forcing is provided in section 6 .

\subsection{Second precipitation event ( 28 to 30 July)}

Between 24 and 27 July an Indian Monsoon Depression (IMD) moved from the Bay of Bengal northwestward across India (Figure 8(b), (d) and (f)). A surface wind maximum (low-level jet) located between the surface low and the Himalayan foothills extended from the Bay of Bengal toward northeastern Pakistan (Figure 8(b) and (d)). This southeasterly flow was further enhanced by the strong anticyclone located over the Tibetan Plateau (Houze et al.,
2011). On 27 July the low pressure system/trough reached northwestern India and a second (westerly) surface wind maximum (low-level jet of approximately $8-10 \mathrm{~m} \mathrm{~s}^{-1}$ ) located along the southern edge of the trough brought air from the Arabian Sea towards northeastern Pakistan. The two low-level jets converged over northeastern Pakistan (Figure 8). The convergence of the moist air masses is nicely illustrated by a set of back trajectories started from the precipitation area over Pakistan on 0600 UTC 29 July (Figure 7(b)). Concomitantly area-mean PW over northeastern Pakistan reached its maximum value for the month of July of nearly $50 \mathrm{~mm}$ at 1800 UTC 28 July (Figure 5) and the sounding at 0000 UTC 28 July indicates near-saturation conditions throughout the troposphere (not shown, see Houze et al., 2011; Galarneau et al., 2012).

Distinct evaporation maxima were located along the pathway of the air from the Indian Ocean to Pakistan. At 1200 UTC 25 July evaporation maxima were located over the northern Bay of Bengal, aligned in a band parallel to the Himalayas, and over northeastern Pakistan $\left(>3 \mathrm{~mm}(6 \mathrm{~h})^{-1}\right.$, see Figure 8(b)).

At upper levels a positive PV anomaly was present over Afghanistan from 27 July onwards. This anomaly was the southern tip of a planetary-scale wave-breaking event that 

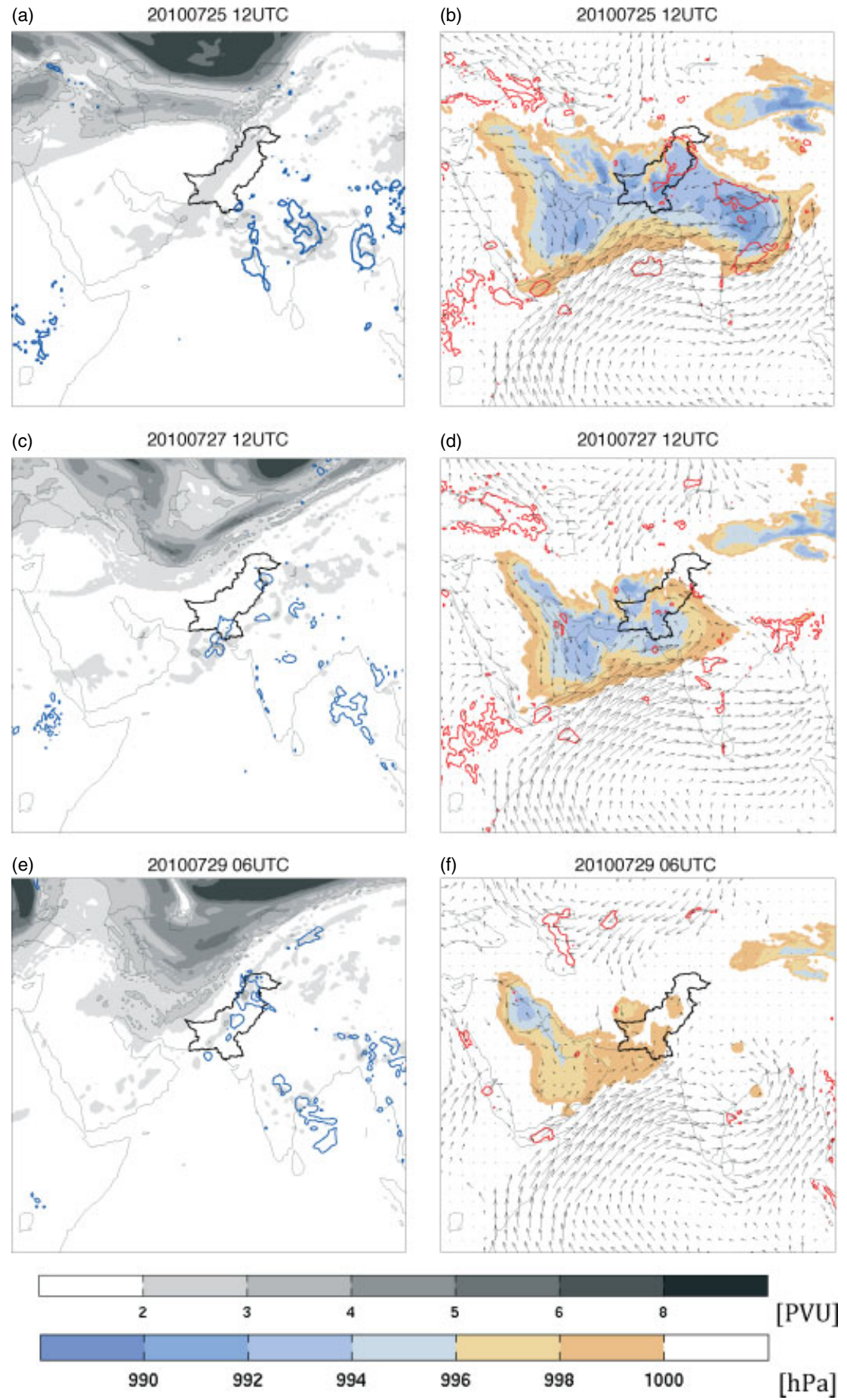

Figure 8. As Figure 6 but at 1200 UTC 25 July (a) and (b), 1200 UTC 27 July (c) and (d), and 0600 UTC 29 July 2010 (e) and (f).

extended southwards along the eastern flank of the blocking anticyclone over Russia (Figure 8). Compared to the first episode the upper-level PV anomaly was of significantly larger spatial scale and higher amplitude but also located farther away from Pakistan. The upper-level positive PV anomaly moved southeastward over the next two days and intense precipitation occurred on 29 July along the eastern flank of the upper-level anomaly (Figure 8(e)). Satellite observations show a large-scale alignment of the precipitation in northeastern Pakistan along the eastern flank of the upper-level PV anomaly throughout the entire event. Extensive stratiform clouds were interspersed with MCSs. A distinct MCS was present over the Peshawar area. The precipitation that fell over western Pakistan was predominantly convective.

In summary, during both intense precipitation phases monsoonal surface flow features (heat-low, IMD) played an important role during the early stages of the events and were central for the transport of moist air from the Arabian Sea and the Bay of Bengal towards northeastern Pakistan. Positive upper-level PV anomalies, which had formed along the eastern flank of the blocking anticyclone over Russia and reached Afghanistan and Pakistan from the extratropics, then played a crucial role in intensifying and prolonging the precipitation events. In contrast to the first precipitation episode, where the initiation of the precipitation happened 
independently of the upper-level forcing, the upper-level forcing played a more prominent role in the initiation and spatial organization of the precipitation during the second event. A detailed analysis of the effects of the upper-level PV anomalies is presented in the next section.

\section{Quantification of the impact of the upper-level flow}

Studies for instance in the Alpine area (Massacand et al., 1998) and the subtropical Pacific (Funatsu and Waugh, 2008) have shown that upper-level positive PV anomalies can enhance precipitation by: (i) ensuring transport of moisture towards the precipitation area; (ii) being associated with a low-level wind field oriented perpendicular to the topographic barrier; (iii) destabilizing the atmosphere; and (iv) quasi-geostrophic forcing of ascent. To quantify the influence of the upper-level flow on the low-level circulation and stability, a piecewise PV inversion of the upper-level positive PV anomalies over Pakistan was carried out at 0000 UTC 22 July and 0600 UTC 29 July. In addition the application of the quasi-geostrophic omega equation on the analysis fields allowed estimating quasi-geostrophically forced ascent (Clough et al., 1996; Gray and Dacre, 2006). Quasi-geostrophically forced vertical winds were estimated at $300 \mathrm{hPa}$ and $500 \mathrm{hPa}$. The basis for these estimates was the troposphere above $500 \mathrm{hPa}$.

The PV inversion shows that the upper-level anomalies had a significant impact on the orientation and amplitude of the flow field in the lower troposphere at $850 \mathrm{hPa}$. During the first event (20 to 22 July) low-level winds converged in northeastern Pakistan (Figures 6, 7(a) and 9(a)). After the removal of the upper-level anomaly, the lowlevel flow was directed towards the Arabian Sea away from the precipitation region in northeastern Pakistan at $850 \mathrm{hPa}$ and above (Figure 9(c)). Below $850 \mathrm{hPa}$ the influence of the upper-level PV anomaly on the wind field became negligible. The analysis of the upper-level quasi-geostrophic forcing of vertical motion over Pakistan indicated forced lifting over Pakistan throughout the entire episode at $300 \mathrm{hPa}$ but the signal only extended down to $500 \mathrm{hPa}$ at 0600 and $1800 \mathrm{UTC}$ 21 July and was relatively weak during the rest of the episode (Figure 10(a)).

The upper-level PV anomaly had an even stronger effect on the low-level wind field during the 29 July event. Again a major component of the low-level wind field was oriented perpendicular to the Himalaya mountains in northeastern Pakistan (Figure 9(b)). A coherent band of southwesterly winds extended from the Arabian Sea to northeastern Pakistan. Without the upper-level PV anomaly the wind over Pakistan became very weak (Figure 9(d)). An area of very weak quasi-geostrophic lifting at $500 \mathrm{hPa}$ was present upstream over Afghanistan and Pakistan consistent with the relatively weak upper-level temperature gradients over Pakistan (Figure 10(b)).

Hence during both precipitation episodes the effect of the upper-level PV anomalies on the mid-tropospheric vertical wind field was detectable only for limited amounts of time. The main effect of the PV anomalies was to orient the horizontal lower-tropospheric flow perpendicular to the mountains and thereby to potentially force orographic lifting (see also Houze et al., 2011). This effect was especially pronounced during the second precipitation event, which can be explained by the larger spatial scale of the upperlevel PV anomaly. The orographic lifting is confirmed by an evaluation of the fraction of air parcels that were lifted from the lowermost troposphere across the mountains surrounding Pakistan (i.e. fraction of trajectories that reached $40^{\circ} \mathrm{N}$ ) based on forward trajectories started from northeastern Pakistan from below $750 \mathrm{hPa}$. The time series shows a strong correlation between the number of trajectories crossing the mountains and the presence of the upper-level PV anomalies. Almost 50\% of all the air parcels were lifted across the topographic barrier and reached $40^{\circ} \mathrm{N}$ during the precipitation events (Figure 1).

\section{The moisture source conundrum}

The Eulerian analyses presented so far suggest that the Arabian Sea, the Bay of Bengal, and land evaporation along the foothills and in northern Pakistan might be important sources of moisture for the precipitation events over Pakistan. Disentangling the various moisture source contributions is challenging, as evaporation maxima were present along the pathways of the air from the ocean to Pakistan during both episodes. An important aspect (especially for the second precipitation event) is the question of where the high moisture content of the usually very dry middle troposphere over Pakistan stems from.

\subsection{Trajectory analyses}

The pathways of the air masses that reached the precipitation areas over northeastern Pakistan (relative humidity >95\%) at 0000 UTC on 22 July can be separated into three distinct branches (Figure 7(a)). One branch reached Pakistan from the northwest at a height of approximately $500 \mathrm{hPa}$. This air was fairly dry in absolute terms $\left(q<5 \mathrm{~g} \mathrm{~kg}^{-1}\right)$. A second branch reached Pakistan from the Arabian Sea. These air masses were very moist $\left(12-23 \mathrm{~g} \mathrm{~kg}^{-1}\right)$ and located in the lowermost layers of the atmosphere over the Indian Ocean (Figure 7(c) and (e)). A third set of trajectories reached northern Pakistan from the Indian continent. These air parcels were also very moist $\left(12-22 \mathrm{~g} \mathrm{~kg}^{-1}\right)$. The majority of the trajectories that reached Pakistan at 0000 UTC 22 July spent more than 72 hours over land prior to the precipitation event. Very similar trajectory pathways were found for a precipitation event that occurred in 2003 over eastern Pakistan (Medina et al., 2010). A notable difference during the July 2010 event was the third trajectory bundle that reached Pakistan from the south over the Indian subcontinent (Figure $7(a)$ ), which was not present in the 2003 event.

Moisture source regions identified from the quantitative Lagrangian moisture source diagnostic show a large maximum of evaporation contribution from local land areas (Figure 11(a)). The moisture source region information can be interpreted as distributing the total rainfall from the boundary layer and the free troposphere in the target domain during the period 18-24 July over the respective source region. To facilitate a quantitative comparison between the two precipitation episodes, the total evaporation contribution was subdivided into seven geographical regions, as indicated in Figure 11(a).

Largest contributions originated locally from the land areas of Pakistan (59\%, region 3) and west of $70^{\circ} \mathrm{E}(19 \%$, region 2). An additional significant contribution stems from the Indian subcontinent $(9.2 \%$, region 6$)$, while only minor moisture amounts originated from directly east of $78^{\circ} \mathrm{E}$ 
(a)

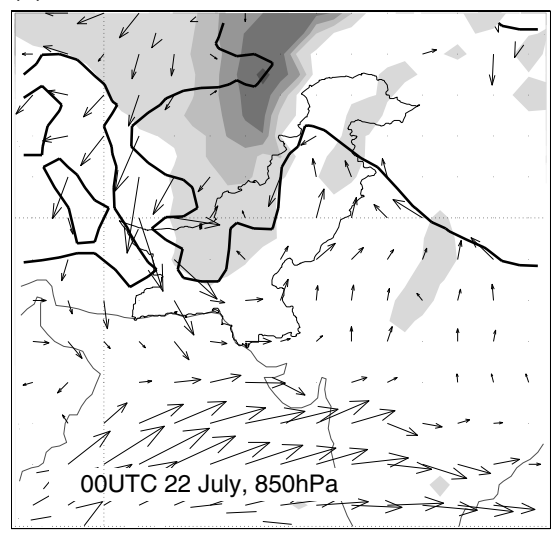

(c)

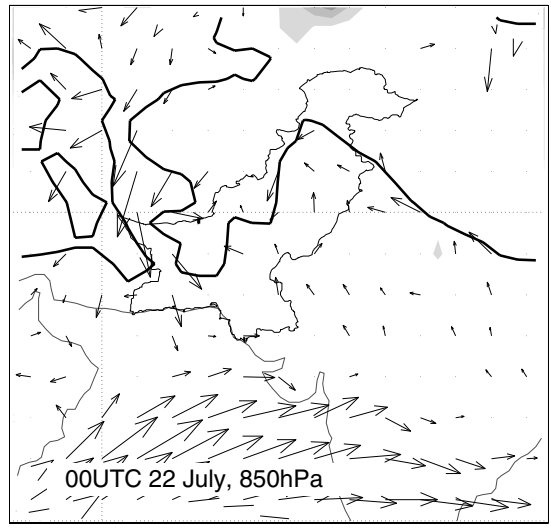

(b)

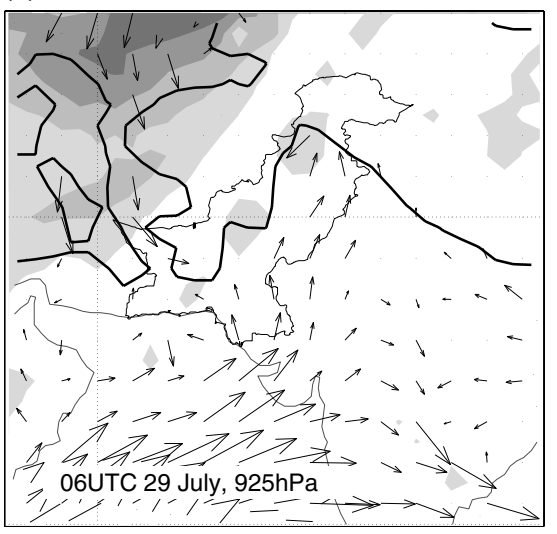

(d)

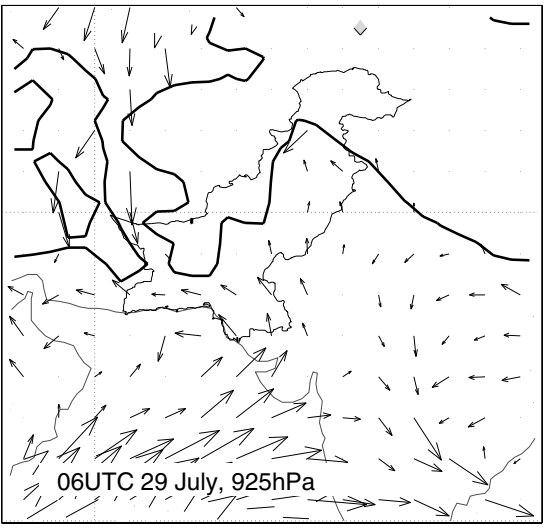

$[\mathrm{PVU}]$

Figure 9. PV on the $340 \mathrm{~K}$ isentropic level (shaded, PVU) and wind at 850 and $925 \mathrm{hPa}\left(\mathrm{m} \mathrm{s}^{-1}\right)$ in the ECMWF analysis (a) and (b) and after the PV inversion (c) and (d). The solid black line corresponds to the $1000 \mathrm{~m}$ a.s.l. isoline. The panels in the first column (a) and (c) show the situation at 0000 UTC 22 July 2010 and the panels in the second column (b) and (d) show the situation at 0600 UTC 29 July.

(a)

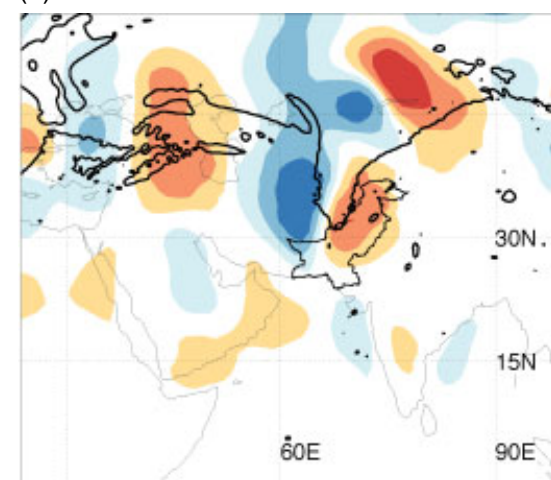

(b)

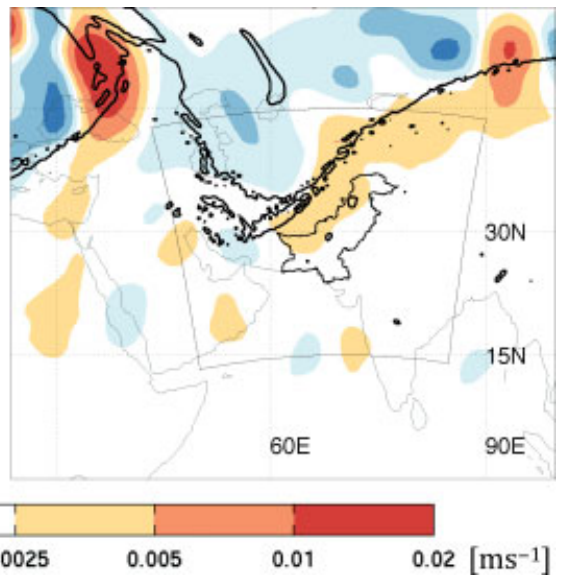

Figure 10. Quasi-geostrophic forcing of vertical motion $\left(\mathrm{m} \mathrm{s}^{-1}\right.$ ) at (a) 0000 UTC 22 July 2010 and (b) at 0600 UTC 29 July (shaded) and dynamical tropopause (2 PVU isoline) on $340 \mathrm{~K}$ (black line). Note that the colour scale is nonlinear. The thin black line in panel (b) is the COSMO domain.

(3.3\%, region 4$)$ and north of $37^{\circ} \mathrm{N}(0.1 \%$, region 1$)$ (see Table 1 for more details). While this diagnostic identifies a region in the Arabian Sea as moisture source, which also coincides with an elongated branch of trajectories (Figure 7(a)), the overall direct contribution of the oceanic source regions was rather small with $8.9 \%$ from the Arabian Sea (region 5) and $0.3 \%$ from the Bay of Bengal (region 7). In conjunction with the insight gained from Figures 6 and 7, these numbers point to the important role of the intense coupling of precipitation and evapotranspiration periods, potentially with intercept storage playing a role.

To investigate the sources of the moisture in the free troposphere over Pakistan the same procedure was applied to air masses located above $700 \mathrm{hPa}$ over northeastern Pakistan (Figure 11(c) and Table 2). The uptake of this moisture occurred mainly locally over central and eastern 
Table 1. Contributions of the evaporation (\%) over various regions to the moisture that rained out over Pakistan.

\begin{tabular}{lccccccc}
\hline Region & $\mathbf{1}$ & $\mathbf{2}$ & $\mathbf{3}$ & $\mathbf{4}$ & $\mathbf{5}$ & $\mathbf{6}$ & $\mathbf{7}$ \\
\hline 18-24 July & 0.13 & 19.0 & 59.1 & 3.3 & 8.9 & 9.2 & 0.3 \\
26-30 July & 0.1 & 4.1 & 30.0 & 10.3 & 31.8 & 18.9 & 4.7 \\
\hline
\end{tabular}

Periods: 18-24 July 2010 and 26-30 July 2010. See Figure 11 for definition of Regions 1-7.
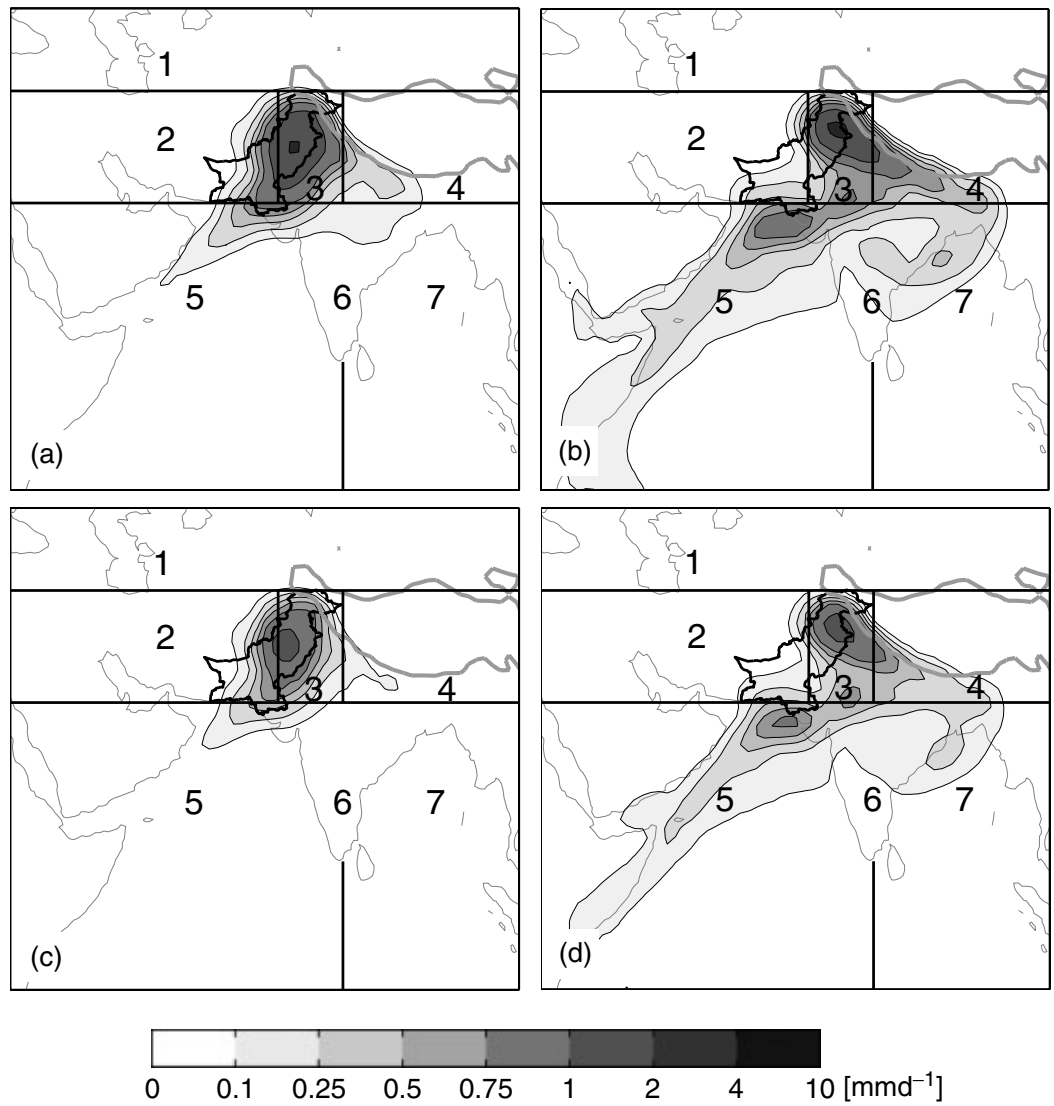

Figure 11. Moisture uptake in the boundary layer and in the free troposphere (shaded, mm day ${ }^{-1}$ ) calculated along trajectories started from the precipitation area over Pakistan between 18 and 24 July 2010 (a) and between 26 and 31 July (b). The solid grey line indicates the 4000 m a.s.l. isoline. Numbers indicate regions used for the moisture source classification. Moisture uptake in the boundary layer and in the free troposphere calculated along trajectories started from the precipitation area over Pakistan above the boundary layer ( $<700 \mathrm{hPa})$ between 18 and 24 July (c) and between 26 and 31 July (d). Note the nonlinear shade bar.

Pakistan (Figure 11(c), 26.4\% region 2 and 52.6\% region 3), with small contributions from over the Arabian Sea (9.3\% region 5). This is further illustrated by a subset of trajectories that were started from nearly saturated air masses over northeastern Pakistan above $700 \mathrm{hPa}$ on 22 July 0000 UTC (Figure 7(e)). A substantial fraction of the moist air masses that reached the free troposphere over Pakistan from the Indian Ocean was located within the boundary layer along its passage from the Indian Ocean to northeastern Pakistan (Table 3) and lifted above $700 \mathrm{hPa}$ during the last 24 hours over northeastern Pakistan. Moisture advection in the free atmosphere therefore played a minor role in moistening the free troposphere over Pakistan for this event. The relatively dry air masses that reached Pakistan from the northwest
Table 3. Percentage of all trajectories started from the free troposphere $(<700 \mathrm{hPa})$ over northeastern Pakistan that were located between $700 \mathrm{hPa}$ and the surface, at time lags between 0 and -96 hours.

\begin{tabular}{lccccc}
\hline$\%$ & $\mathbf{0 h}$ & $-\mathbf{2 4} \boldsymbol{h}$ & $\mathbf{- 4 8} \boldsymbol{h}$ & $\mathbf{- 7 2} \boldsymbol{h}$ & $\mathbf{- 9 6} \boldsymbol{h}$ \\
\hline 0000 UTC 22 July & 0 & 67 & $>90$ & $>90$ & $>90$ \\
0600 UTC 29 July & 0 & 50 & 65 & 75 & 82 \\
\hline
\end{tabular}

See also Figure $7(\mathrm{e})$ and (f).

ended up in the free troposphere above $700 \mathrm{hPa}$ (Figure 7(a), (c) and (e)).

The trajectories calculated for the second precipitation event (28-30 July) yield a picture that is similar to the

Table 2. As Table 1 but for air parcels in the free troposphere $(<700 \mathrm{hPa})$ over northeastern Pakistan.

\begin{tabular}{lccccccc}
\hline Region & $\mathbf{1}$ & $\mathbf{2}$ & $\mathbf{3}$ & $\mathbf{4}$ & $\mathbf{5}$ & $\mathbf{6}$ & $\mathbf{7}$ \\
\hline 18-24 July & 0.26 & 26.5 & 52.6 & 2.7 & 9.3 & 8.4 & 0.3 \\
26-30 July & 0.1 & 3.8 & 26.9 & 9.5 & 33.6 & 21.7 & 4.5 \\
\hline
\end{tabular}


preceding one, but differs in decisive aspects. The majority of the trajectories reached northeastern Pakistan from the southeast, either following a pathway from the Bay of Bengal along the foothills of the Himalayas or originating from far into the Arabian Sea and across the Indian subcontinent (Figure 7(b)). Compared to the first event there were only a few very dry air parcels that reached Pakistan from the land area over Afghanistan (Figure 7(a) and (b)). The pathways of the air parcels that reach the free troposphere over Pakistan are very similar to those of the air parcels that remained below $700 \mathrm{hPa}$ (Figure 7(d) and (f)).

The relatively subtle changes in air-mass transport induced a quite substantial change in moisture source contributions compared to the previous precipitation event (Figure 11(b) and Table 1). Local moisture source contributions were markedly less relevant, with $30 \%$ from Pakistan (region 3) and $4.1 \%$ from the areas adjacent to the west (region 2). The area along the Himalayan foothills to the east had a larger contribution (10.3\%, region 4 ), and in particular the Indian subcontinent appeared as a prominent source region during this second event (18.9\%, region 6). Most remarkable are however the increases in oceanic moisture contributions compared to the first event, with a four-fold increase of contributions from the Arabian Sea $(31.8 \%$, region 5$)$ and a larger fraction from the Bay of Bengal $(4.7 \%)$ amounting to a total of approximately $37 \%$. The moisture uptake areas for the air that reached the free troposphere over Pakistan $(>700 \mathrm{hPa})$ were very similar to the overall moisture uptake areas (Figure 11(d) and Table 2) and $37.9 \%$ of the moisture stems directly from the Indian Ocean (regions 5 and 7). The fraction of trajectories that remained in the boundary layer during the 96 hours prior to their arrival over Pakistan was lower than in the previous case; however, still more than $50 \%$ of the trajectories remained in the boundary layer until 24 hours prior to their arrival (Table 3 ). The advective contribution in the free troposphere was hence larger than during the first episode.

Compared to the climatological moisture origin during July (taking the years 2000-2004 as a reference period), no unusual moisture sources contributed to the event, but evapotranspiration over an area ranging from southern Pakistan to the Bay of Bengal, the Bay of Bengal itself and the Arabian Sea had much larger contributions to precipitation in the target area than on average during July 2000-2004 (not shown).

\subsection{Model simulations}

The effect of the land evaporation on the precipitation is quantified using model experiments. Simulations with the COSMO model were run for the time period 24 to 31 July (see section 2.3 for more information). A sensitivity experiment was performed to expand and confirm the findings of the Lagrangian analyses. Both precipitation events were well reproduced in the COSMO control run. The focus of the sensitivity experiment was set on the second, larger precipitation event that occurred from 28 to 30 July. For the sensitivity experiment surface evapotranspiration was shut off over Pakistan (box in Figure 12(b)) three days prior to the onset of the precipitation event. This relatively short time period was chosen to minimize modifications of the circulation by the altered fluxes and hence to ensure that changes in model precipitation are primarily due to changes in moisture availability.

The accumulated precipitation between 28 and 30 July in the COSMO control run amounted to up to $407 \mathrm{~mm}$ locally (Figure 12(a)) and substantial amounts of precipitation fell across large parts of northeastern Pakistan. The agreement of the simulated precipitation with the ECMWF shortrange forecast precipitation and also with the observations is very good (Figure 2). In the experiment, precipitation maxima reached only $104.5 \mathrm{~mm}$. Area-averaged differences in precipitation over northeastern Pakistan $\left(30^{\circ} \mathrm{N}\right.$ to $37^{\circ} \mathrm{N}$, $70^{\circ} \mathrm{E}$ to $75^{\circ} \mathrm{E}$ ) amounted to approximately $44 \mathrm{~mm}$. This corresponds to a reduction by approximately $80 \%$ in the experiment compared to the control simulation. This went in tandem with a reduction of the PW over Pakistan by up to $10 \mathrm{~mm}$ ( $15 \%$ to $18 \%$ of the total PW, Figure $12(\mathrm{c})$ ). The differences in absolute moisture were not confined to the lowest level but rather extended up to the middle troposphere (Figure 12(d)).

There is a band of higher precipitation over the Indian Ocean in the experiment (Figure 12(b)). Before the start of the precipitation event the suppressed evaporation over Pakistan leaves the dynamics mostly unchanged compared to the reference experiment, which is necessary to interpret the absence of the simulated precipitation in the experiment run as a direct effect of the suppressed surface evaporation.

However after 28 July due to the absence of the precipitation over Pakistan, nonlinear effects lead to slightly changed patterns of wind and pressure and a changed moisture distribution at the Pakistan coast. Higher values of PW and the slightly changed dynamics over the ocean lead to enhanced precipitation over the Indian Ocean.

In summary a significant fraction of the moisture that rained out over Pakistan was not transported directly from the Indian Ocean to the precipitation areas over northeastern Pakistan but stemmed from land evapotranspiration. Nevertheless, evaporation over the warm Indian Ocean was also important for the precipitation event: approximately $35 \%$ of the moisture that rained out over northeastern Pakistan evaporated there and was transported directly from the Indian Ocean to the precipitation area.

\section{Summary and conclusions}

A series of precipitation events of increasing intensity occurred over Pakistan in July 2010. The precipitation resulted in the flooding of significant parts of the country. In this article the last two precipitation events (20-22 July and 28-30 July) are investigated in detail. The analyses comprise both a discussion of local forcing factors and large-scale boundary conditions. Here we provide a summary of the findings by answering the main questions of this study as formulated in the introduction.

What were the main precipitation supporting factors?

Prior to and during the early phases of both precipitation episodes monsoonal low-level flow features (heat-lows, Indian monsoon depression) were central for the transport and convergence of moist air into northeastern Pakistan (see also Houze et al., 2011; Galarneau et al., 2012). Precipitation was organized and invigorated by upper-level positive PV anomalies that reached Pakistan from the extratropics. A detailed analysis of the role of the upper-level PV anomalies, using PV inversion and the quasi-geostrophic omega equation, showed that: (i) the upper-level PV 
(a)

(b)

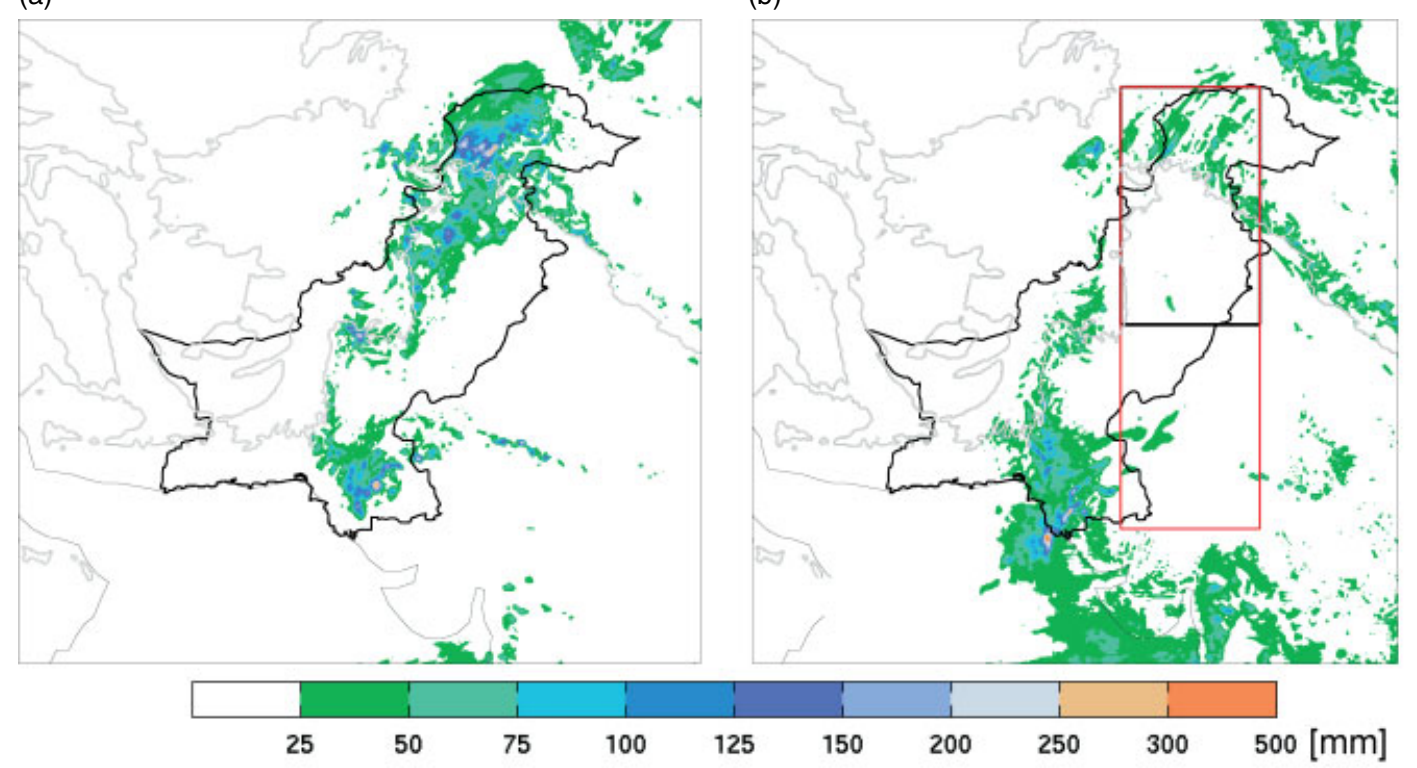

(c)

(d)
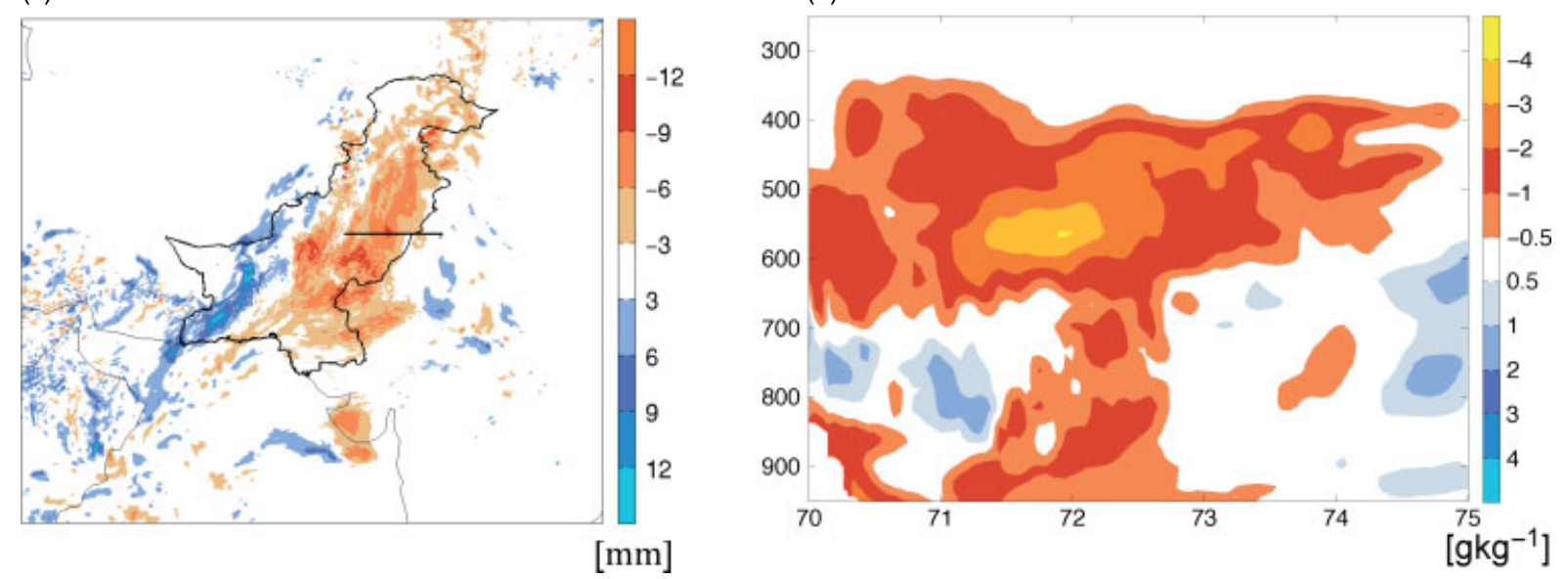

Figure 12. (a) Control simulation accumulated precipitation between 0000 UTC 28 July and 0000 UTC 30 July 2010 (mm) and 1000 m a.s.l. model topography contour (grey line); (b) same but for the experiment with humidity fluxes shut off over Pakistan; (c) difference in precipitable water (mm) between the experiment and the control simulation at 0000 UTC 28 July; (d) cross-section taken along $30^{\circ} \mathrm{N}$ at 0000 UTC 28 July (solid line in panel (c)) showing the difference in absolute moisture $\left(\mathrm{g} \mathrm{kg}^{-1}\right)$ between the experiment and the control simulation. The large red rectangle in panel (b) indicates the area where the humidity fluxes were shut off, the smaller black rectangle is the area for which the precipitation statistics were calculated.

anomalies induced a surface wind field with a major component oriented perpendicular to the mountains in northeastern Pakistan; (ii) a significant fraction (>50\%) of these air masses were lifted over the mountains surrounding northeastern Pakistan (i.e. they reached $40^{\circ} \mathrm{N}$ ); (iii) forced quasi-geostrophic ascent was relatively weak and mostly confined to the upper-troposphere; and (iv) the stratification of the lower to middle troposphere over Pakistan was not significantly affected by the upper-level anomalies.

What was the origin of the abundant moisture that rained out over Pakistan and along which pathways was the moisture transported to the precipitation area?

Moisture was transported towards northeastern Pakistan both from the Arabian Sea and the Bay of Bengal. The Arabian Sea was the more relevant source for both events (8.9\% during the first episode and $31.8 \%$ during the second episode compared to $0.3 \%$ and $4.7 \%$ from the Bay of Bengal, see also Table 1 and Figure 11). The majority of the air masses spent at least 72 hours over land before reaching the precipitation areas and on the way from the Indian Ocean to northeastern Pakistan a significant part of the moisture that rained out over Pakistan was processed over the continent via precipitation and re-evaporation (more than $90 \%$ for the first event and more than $60 \%$ for the second event). Land-atmosphere interactions were therefore of central importance for both heavy precipitation episodes. During the second precipitation episode an unusually moist free troposphere over northeastern Pakistan was crucial for the intensity of the precipitation event (Houze et al., 2011). These moist conditions were favoured by two factors: (i) during the second episode very little dry air from the northwest reached northeastern Pakistan (Figure 7); and (ii) very moist air from the boundary layer was lifted up into the free troposphere over northeastern Pakistan and along the Himalayan foothills over India.

How unusual was the large-scale flow situation?

We compared the flow conditions and SSTs in the Indian Ocean in July 2010 to the ERA-Interim climatology (1989 to 2009) and calculated normalized anomalies (in units of standard deviations (STD)). A number of boundary conditions were conducive for enhanced precipitation over India in July 2010. Above-normal SST in the Indian Ocean 
( $>2$ STD) led to significantly enhanced evaporation $(>2$ STD) over the Arabian Sea and above-normal PW values and a deep moist air layer over the Arabian Sea and southern India (Figures 3 and 4). Very dry conditions were present to the north of Pakistan ( -2 to -3 STD). An inversion at the boundary between these dry air masses in the north and very moist air in the south potentially promoted the formation of strong convection in the early phase of the first precipitation episode (see also Houze et al., 2007).

An anomalous lower tropospheric wind field directed from the Gulf of Bengal towards northeastern Pakistan contributed to the convergence of moist air over Pakistan and the transport of moisture from the Bay of Bengal and India towards Pakistan. This low-level flow configuration was driven by Indian monsoon depressions (Houze et al., 2011; Galarneau et al., 2012) and resembled the rainpromoting synoptic situation described by Rahmatullah (1952). The wind anomaly potentially also contributed to the slightly above normal (1-1.5 STD) evaporation over land along the Himalayan foothills.

A positive feedback between convection and wet soil moisture anomalies (e.g. Beljaars et al., 1996) could have contributed to the intensity of both precipitation events in the second half of July. The wet soil moisture anomalies were created by precipitation events early in July; soil conditions in spring and early summer had been drier than normal. On top of all these favourable boundary conditions, two longlasting and slow-moving synoptic-scale breaking waves, i.e. positive upper-level PV anomalies, formed northwest of Pakistan. These upper-level PV anomalies were associated with a low-level wind field that exhibited strong convergence over northeastern Pakistan and was oriented perpendicular to the mountains in northeastern Pakistan and thereby promoted orographic lifting of very moist air masses. This resulted in substantial, persistent and spatially organized large-scale and convective precipitation.

The frequency of extratropical wave-breaking events (or positive upper-level PV anomalies) that formed along the downstream flank of the long-lived block over Russia was of statistically significant rarity (>2 STD). This is in good agreement with the observation of Webster et al. (2011) that the number of extreme precipitation events was exceptional.

\section{Acknowledgements}

We thank the four anonymous reviewers for their thorough and careful reviews. We thank MeteoSwiss for granting access to the ECMWF analysis and re-analysis data. We thank Tim Hewson and Linda Schlemmer for valuable discussions. GRACE land data were processed by Sean Swenson, supported by the NASA MEASURES Program, and are available at http://grace.jpl.nasa.gov. SS and EM acknowledge funding from the Swiss National Science Foundation (Project 200021-130079), and MG from the ETH research grant ETH-20 10-2.

\section{References}

Akthar S. 2011. The south Asiatic monsoon and flood hazards in the Indus river basin, Pakistan. J. Basic Appl. Sci. 7: 101-115.

Albergel C, Balsamo G, de Rosnay P, Muñoz-Sabater J, Boussetta S. 2012. A bare ground evaporation revision in the ECMWF landsurface scheme: Evaluation of its impact using ground soil moisture and satellite microwave data. Hydrol. Earth Syst. Sci. Discuss. 9: 6715-6752.
Alexander MA, Bladé I, Newman M, Lanzante JR, Lau N-G, Scott JD. 2002. The atmospheric bridge: The influence of ENSO teleconnections on air-sea interaction over the global oceans. J. Climate 15: 2205-2231.

Altenhoff AM, Martius O, Croci-Maspoli M, Schwierz C, Davies HC. 2008. Linkage of atmospheric blocks and synoptic-scale Rossby waves: A climatological analysis. Tellus 60A: 1053-1063.

Barriopedro D, Fischer EM, Luterbacher J, Trigo RM, García-Herrera R. 2011. The hot summer of 2010: Redrawing the temperature record map of Europe. Science 332: 220-224.

Beljaars ACM, Viterbo P, Miller MJ, Betts AK. 1996. The anomalous rainfall over the United States during July 1993: Sensitivity to land surface parameterization and soil moisture anomalies. Mon. Weather Rev. 124: 362-383.

Clough SA, Davitt CSA, Thorpe AJ. 1996. Attribution concepts applied to the omega equation. Q. J. R. Meteorol. Soc. 122: 1943-1962.

Dee DP, Uppala SM, Simmons AJ, Berrisford P, Poli P, Kobayashi S, Andrae U, Balmaseda MA, Balsamo G, Bauer P, Bechtold P, Beljaars ACM, van de Berg L, Bidlot J, Bormann N, Delsol C, Dragani R, Fuentes M, Geer AJ, Haimberger L, Healy SB, Hersbach H, Hólm EV, Isaksen L, Kållberg P, Köhler M, Matricardi M, McNally AP, Monge-Sanz BM, Morcrette J-J, Park B-K, Peubey C, de Rosnay P, Tavolato C, Thépaut J-N, Vitart F. 2011. The ERA-Interim reanalysis: Configuration and performance of the data assimilation system. Q. J. R. Meteorol. Soc. 137: 553-597.

Dickinson RE. 1984. Modeling evapotranspiration for three-dimensional global climate models. Geophysical Monograph Series 29: 58-72.

Dobler A, Ahrens B. 2010. Analysis of the Indian summer monsoon system in the regional climate model COSMO-CLM. J. Geophys. Res. 115: D16101, DOI: 10.1029/2009JD013497.

Dole R, Hoerling MP, Perlwitz J, Escheid J, Pegion P, Zhang T, Quan XW, Xu TY, Murray D. 2011. Was there a basis for anticipating the 2010 Russian heat wave? Geophys. Res. Lett. 38: L06702, DOI: 10.1029/2010GL046582.

Doms G, Schättler U. 2002. 'A description of the nonhydrostatic regional model LM. Part I: Dynamics and numerics.' Deutscher Wetterdienst, 134 pp.

Doswell III CA, Ramis C, Romero R, Alonso S. 1998. A diagnostic study of three heavy precipitation episodes in the western Mediterranean region. Weather and Forecasting 13: 102-124.

Emanuel KA, Živković-Rothman M. 1999. Development and evaluation of a convection scheme for use in climate models. J. Atmos. Sci. 56: $1766-1782$.

Fehlmann R. 1997. 'Dynamics of seminal PV elements.' $\mathrm{PhD}$ thesis, Laboratory for Atmospheric Physics, ETH Zurich, 143 pp.

Funatsu BM, Waugh DW. 2008. Connections between potential vorticity intrusions and convection in the eastern tropical Pacific. J. Atmos. Sci. 65: $987-1002$.

Galarneau Jr TJ, Dole RM, Hamill TM, Perlwitz J. 2012. A multiscale analysis of the extreme weather events over western Russia and northern Pakistan during July 2010. Mon. Weather Rev. 140: 1639-1664.

Gray SL, Dacre HF. 2006. Classifying dynamical forcing mechanisms using a climatology of extratropical cyclones. Q. J. R. Meteorol. Soc. 132: 1119-1137.

Hong C-C, Hsu H-H, Lin N-H, Chiu H. 2011. Roles of European blocking and tropical-extratropical interaction in the 2010 Pakistan flooding. Geophys. Res. Lett. 38: L13806, DOI: 10.1029/2011GL047583.

Houze Jr RA, Wilton DC, Smull BF. 2007. Monsoon convection in the Himalayan region as seen by the TRMM Precipitation Radar. Q. J. R. Meteorol. Soc. 133: 1389-1411.

Houze Jr RA, Rasmussen KL, Medina S, Brodzik SR, Romatschke U. 2011. Anomalous atmospheric events leading to the summer 2010 floods in Pakistan. Bull. Am. Meteorol. Soc. 92: 291-298.

Huffman GJ, Adler RF, Morrissey MM, Bolvin DT, Curtis S, Joyce R, McGavock B, Susskind J. 2001. Global precipitation at one-degree daily resolution from multisatellite observations. J. Hydrometeorol. 2: $36-50$.

Huffman GJ, Adler RF, Bolvin DT, Gu GJ, Nelkin EJ, Bowman KP, Hong Y, Stocker EF, Wolff DB. 2007. The TRMM Multisatellite Precipitation Analysis (TMPA): Quasi-global, multiyear, combinedsensor precipitation estimates at fine scales. J. Hydrometeorol. 8: $38-55$.

Lau N-C, Nath MJ. 2000. Impact of ENSO on the variability of the Asian-Australian monsoons as simulated in GCM experiments. J. Climate 13: 4287-4309.

Lau WLM, Kim K-M. 2012. The 2010 Pakistan flood and Russian heat wave: Teleconnection of hydrometeorological extremes. J. Hydrometeorol. 13: 392-403. 
Massacand AC, Wernli H, Davies HC. 1998. Heavy precipitation on the Alpine southside: An upper-level precursor. Geophys. Res. Lett. 25: $1435-1438$.

Massacand AC, Wernli H, Davies HC. 2001. Influence of upstream diabatic heating upon an Alpine event of heavy precipitation. Mon Weather Rev. 129: 2822-2828.

Matsueda M. 2011. Predictability of Euro-Russian blocking in summer of 2010. Geophys. Res. Lett. 38: L06801, DOI: 10.1029/2010GL046557.

Medina S, Houze Jr RA, Kumar A, Niyogi D. 2010. Summer monsoon convection in the Himalayan region: Terrain and land cover effects. Q. J. R. Meteorol. Soc. 136: 593-616.

Palmer TN, Branković Č, Viterbo P, Miller MJ. 1992. Modeling interannual variations of summer monsoons. J. Climate 5: 399-417.

Rahmatullah M. 1952. Synoptic aspects of the monsoon circulation and rainfall over Indo-Pakistan. J. Meteorol. 9: 176-179.

Rodewald M. 1936. Bemerkungen zu Karl Wien: Die Wetterverhältnisse am Nanga Parbat während der Katastrophe auf der deutschen Himalaja-Expedition 1934. Meteorol. Z. 53: 182-185.

Schlemmer L, Martius O, Sprenger M, Schwierz C, Twitchett A. 2010 Disentangling the forcing mechanisms of a heavy precipitation even along the Alpine south side using potential vorticity inversion. Mon. Weather Rev. 138: 2336-2353.

Schneidereit A, Schubert S, Vargin P, Lunkeit F, Zhu XH, Peters DHW, Fraedrich K. 2012. Large-scale flow and the long-lasting blocking high over Russia: Summer 2010. Mon. Weather Rev. 140: 2967-2981.

Sodemann H, Stohl A. 2009. Asymmetries in the moisture origin of Antarctic precipitation. Geophys. Res. Lett. 36: L22803, DOI: 10.1029/2009GL040242.

Sodemann H, Schwierz C, Wernli H. 2008. Interannual variability of Greenland winter precipitation sources: Lagrangian moisture diagnostic and North Atlantic Oscillation influence. J. Geophys. Res. 113: D03107, DOI: 10.1029/2007JD008503.

Sprenger M. 2007. 'Numerical piecewise potential vorticity inversion: A user guide for real-case experiments.' Masters thesis, FHSS Schweiz, ETH Zurich, 87 pp.
Steppeler J, Doms G, Schättler U, Bitzer HW, Gassmann A, Damrath U, Gregoric G. 2003. Meso-gamma scale forecast using the nonhydrostatic model LM. Meteorol. Atmos. Phys. 82: 75-96.

Stohl A, Foster C, Frank A, Seibert P, Wotawa G. 2005. Technical note: The Lagrangian particle dispersion model FLEXPART version 6.2. Atmos. Chem. Phys. 5: 2461-2474.

Swenson SC, Wahr J. 2006. Post-processing removal of correlated errors in GRACE data. Geophys. Res. Lett. 33: L08402, DOI: $10.1029 / 2005$ GL025285.

Trenberth KE. 1999. Atmospheric moisture recycling: Role of advection and local evaporation. J. Climate 12: 1368-1381.

Tuinenburg OA, Hutjes RWA, Jacobs CMJ, Kabat P. 2011. Diagnosis of local land-atmosphere feedbacks in India. J. Climate 24: 251-266.

USAID. 2010. Pakistan-floods Pakistan Flood. http://www.usaid.gov/ our_work/humanitarian_assistance/countries/pakistan/template/fs_ sr/fy2011/pakistan_fl_fs07_11-30-2010.pdf. Accessed 24 August 2011.

Vogelezang DHP, Holtslag AAM. 1996. Evaluation and model impacts of alternative boundary-layer height formulations. Boundary-Layer Meteorol. 81: 245-269.

Wang S-Y, Davies RE, Huang W-R, Gillies RR. 2011. Pakistan's two-stage monsoon and links with the recent climate change. J. Geophys. Res. 116: D16114, DOI: 10.1029/2011JD015760.

Webster PJ, Toma VE, Kim H-M. 2011. Were the 2010 Pakistan floods predictable? Geophys. Res. Lett. 38: L04806, DOI: 10.1029/2010GL046346.

Wernli H, Davies HC. 1997. A Lagrangian-based analysis of extratropical cyclones. I: The method and some applications. Q. J. R. Meteorol. Soc. 123: 467-489.

Wernli H, Sprenger M. 2007. Identification and ERA-15 climatology of potential vorticity streamers and cutoffs near the extratropical tropopause. J. Atmos. Sci. 64: 1569-1586.

Winschall A, Pfahl S, Sodemann H, Wernli H. 2011. Impact of North Atlantic evaporation hot spots on southern Alpine heavy precipitation events. Q. J. R. Meteorol. Soc. 138: 1245-1258.

Yasunari T. 2006. Land-atmosphere interaction. Ch 11, pp 459-478 in The Asian Monsoon, Wang B (ed). Springer Praxis. 